\title{
Pure Case and Prepositional Case in Russian
}

\author{
Durst-Andersen, Per; Lorentzen, Elena
}

Document Version

Accepted author manuscript

\section{Published in:}

Russian Linguistics

DOI:

10.1007/s11185-017-9177-1

Publication date:

2017

License

Unspecified

Citation for published version (APA):

Durst-Andersen, P., \& Lorentzen, E. (2017). Pure Case and Prepositional Case in Russian. Russian Linguistics, 41(2), 177-221. https://doi.org/10.1007/s11185-017-9177-1

Link to publication in CBS Research Portal

\section{General rights}

Copyright and moral rights for the publications made accessible in the public portal are retained by the authors and/or other copyright owners and it is a condition of accessing publications that users recognise and abide by the legal requirements associated with these rights.

Take down policy

If you believe that this document breaches copyright please contact us (research.lib@cbs.dk) providing details, and we will remove access to the work immediately and investigate your claim. 


\title{
Pure Case and Prepositional Case in Russian Per Durst-Andersen and Elena Lorentzen
}

\author{
Journal article (Accepted manuscript)
}

CITE: Durst-Andersen, P., \& Lorentzen, E. (2017). Pure Case and Prepositional Case in Russian. Russian Linguistics, 41(2), 177-221. 001: 10.1007/s11185-017-9177-1

This is a post-peer-review, pre-copyedit version of an article published in Russian Linguistics.

The final authenticated version is available online at: 10.1007/s11185-017-9177-1

Uploaded to Research@CBS: December २०18 


\title{
Pure Case and Prepositional Case in Russian
}

\author{
Per Durst-Andersen - Elena Lorentzen
}

\begin{abstract}
By considering Russian case as the nominal equivalent to mood whereby its semantic functions are emphasized at the expense of its syntactic functions, it is demonstrated that the nominative, accusative, vocative and genitive cases constitute a mini system in which the nominative and the accusative function as the indicative denoting local reference, the vocative as the imperative demanding local reference and the genitive as the subjunctive denoting non-local reference. At the same time, the genitive enters into another system together with the dative and the instrumental in which they express three different viewpoints, which equally apply to the pure as well as the prepositional case systems. Within the prepositional case system, the accusative and the locative are handled by the notion of contact, while the genitive, dative and the instrumental are treated by the lack of contact - the prepositional analogues to the notion of local reference and non-local reference. It is suggested that the notion 'contact' has had a clear retroactive influence on the function of the accusative in the pure case system.
\end{abstract}

Аннотация Рассматривая категорию падежа в русском языке как эквивалент глагольной категории наклонения и акцентируя тем самым внимание на семантических, а не на синтаксических функциях падежей, авторы статьи показывают, что именительный, винительный, звательный и родительный падежи образуют подсистему, в которой именительный и винительный падежи ведут себя подобно индикативу, обозначая локальную референцию, звательный падеж - подобно императиву, предписывая локальную референцию, и родительный падеж - подобно конъюнктиву, обозначая нелокальную (глобальную) референцию. При этом родительный падеж вместе с дательным и творительным падежами образует другую подсистему, в которой каждый из них обозначает определенную перспективу, что характеризует их употребление как с предлогами, так и без предлогов. Употребление винительного и предложного падежей с предлогами трактуется через понятие контакта, являющегося в предложно-падежной системе аналогом локальной референции, тогда как употребление родительного, дательного и творительного падежей трактуется через понятие отсутствия контакта, являющегося в предложно-падежной системе аналогом глобальной референции. В статье выдвигается гипотеза об обратном влиянии признака 'контакт' на функционирование винительного падежа без предлога.

\section{Introduction}

In this section, we shall take a short look at the main approaches to Russian case with emphasis on the theoretical and practical problems they create. Due to lack of space, we must rely on the reader's knowledge of the more general theories that lie behind the specific case theories. Five groups with different perceptions of Russian case have been identified and will shortly be examined in turn just below.

\subsection{The traditional approach to Russian case}

The first group consists of the overwhelming part of ordinary grammars of the Russian language, which include more or less traditional descriptions of each of the six cases normally recognized in Modern Russian, viz. nominative, accusative, genitive, dative, instrumental, and locative. Here one often finds an extensive and relatively well-documented list of contextual meanings of each 
case form, but frequently with a lack of distinction between primary and secondary uses and between syntactic and semantic functions. The examination of the functions of pure case is often completely disconnected from the examination of prepositional case. All this applies, for instance, to Rozental' 1984; Mulisch 1975, 1993; Švedova \& Lopatin 1989; Mathiassen 1996; Belošapkova 1997; Wade 2011 and to a certain degree to Timberlake 2004. In Wade (2011, p. $105 \mathrm{ff}$.) it is stated that the accusative is used to denote 1) the object of a transitive verb (e.g., On ljubit Mašu 'He loves Masha'; 2) the object in certain impersonal constructions (e.g., Devočku rvet 'The girl feels sick'); 3) duration in time (e.g., Vsju zimu bylo xolodno 'It was cold all winter'); 4) duration in space (e.g., Vsju dorogu oni šli molča 'They walked in silence all the way'); 5) repetition (e.g., On boleet každuju vesnu 'He is ill every spring'); and 6) cost, weight, and measure (e.g., Kniga stoit dollar 'The book costs a dollar'). Only several chapters later in the same book does one find the examination of prepositions, which govern the accusative - and there is no connection whatsoever between these two descriptions. In other traditional grammars, including some reference grammars and normative-descriptive grammars, one finds some connection, but at the cost of a dramatic increase in the number of cases and / or case functions (cf. Pul'kina \& Zaxava-Nekrasova 1975; Švedova 1980; Šeljakin 2001). An attempt to describe Russian case semantics in terms of distributive analysis (cf. Panov 1980, 1999; Klobukov 1986) does not seem to succeed in solving the above-mentioned problems of the traditional grammars. The more recent surveys of grammatical categories by Russian scholars add nothing substantially new from a theoretical point of view to the existing descriptions of Russian case and case semantics (cf. Kustova 2011; Plungjan 2011).

\subsection{Jakobson's case theory}

In his 1936 paper, Jakobson introduces three semantic distinctive features - directionality, quantity, and marginality - used to separate the six cases in Russian. ${ }^{1}$ The accusative and the dative are marked with respect to directionality; the genitive and the locative with respect to quantity; and the instrumental, the dative, and the locative with respect to marginality - the latter feature specifies whether a given case takes a peripheral or central part in the utterance. In this way, we get 'directional cases', i.e., the accusative and the dative, 'quantitative cases', i.e., the genitive and the locative, and 'marginal cases', i.e., the instrumental, the dative and the locative. The combination of features expresses the 'general meaning' of a case, for instance, [+directionality; -quantity; +marginality] in the case of the dative. This is the 'invariant meaning' of the dative. Among the specific meanings of a case, it is possible to find the 'principal meaning', for instance, the indirect object in the case of dative.

One of the big problems with Jakobson's theory is his treatment of the nominative case. It is described as completely unmarked. The nominative's meaning can be extrapolated from the term Karcevski (1927) applied to it, viz. un cas zéro 'a zero case': it is an independent case with no meaning but the lexical meaning which inherently belongs to the noun. The nominative just names a person or a thing and thus seems to be completely separated from the case system. It is a pity that Jakobson's theory has nothing substantial to say about the case form that forms the starting point of any sentence and any utterance. The nominative is the first case learnt by the Russian child (cf. Gvozdev 1961 [1949], p. 162 ff.; Cejtlin 2000, p. 86, 98 ff.; for further evidence, see Ufimceva 1979) and it alternates with the genitive, which is learnt later. The latter is implicitly explained and described in Jakobson 1936 as something additional, i.e., as [+quantity], although one could have explained and described it as a loss of something (loss of local reference) as we shall try to demonstrate later.

Another serious problem is his inclusion of the locative case in the general system as if it had a place within the pure case system. Just as the nominative cannot claim a place within the

\footnotetext{
1 We here deliberately disregard his distinction between Genitive ${ }_{1}$ and Genitive 2 and Locative ${ }_{1}$ and Locative 2 because both distinctions are unproductive in modern Russian, cf. Wierzbicka 1983; 1988, p. 438 ff., and Paus 1994.
} 
prepositional case system, the locative cannot claim a place within the pure case system. We consider this a fundamental defect that threatens the entire building. We believe that they should be described as two separate, but nevertheless, interrelated systems - not as a mixed system.

This being said, it is important to stress that Jakobson's analyses of the differences in meaning between various case forms are notably perceptive. Moreover, he made three insightful observations. First, he made it clear that the grammatical category of case carries its own meaning which cannot be expressed by other means, for instance, by order of occurrence in a sentence. Secondly, he pointed out that the category of case is not a list of equal members: it forms a certain structure and hierarchy. Thirdly, he stressed the semantic functions of Russian case. In the following sections, Russian case will be described as a hierarchical system just like the mood system and the specific functions of its members will be described in purely semantic terms without any reference to syntax.

\subsection{The Government and Binding approach to case}

GB theory operates with two sets of cases: 1) 'structural cases' (in principle, the nominative and the accusative / objective) fully assigned at surface structure, and 2) 'inherent cases' (in principle, all other cases) assigned at deep structure. ${ }^{2}$ According to GB theory some languages know only of structural case (e.g., English), while others know of both types of case (e.g., Russian). Irrespective of that, it does not matter whether a language has morphological case or so-called abstract case - in direct contrast to Jakobson's view.

GB theory also operates with features and markedness, but the notions have quite different content than in Jakobson. In Franks 1995, the features look like Jakobson's semantic features from 1936 and 1958, but they are coupled with syntactic notions. The notion of 'marked' vs. 'unmarked' is used in its everyday sense, i.e., as something extraordinary / peculiar vs. ordinary / unpeculiar. Markedness hierarchies are set up for Russian which show that the accusative case is the most unmarked term $(1995$, p. 52 ff.) and the instrumental case is the most marked one (1995, p. 45).

One fundamental problem with the GB approach is that change of case does not imply change of role:
a. Pacient korčitsja ot boli.
'The patient is writhing in pain'.
b. Pacienta korčit ot boli.
'The patient is writhing with pain'.

According to Babby (1989, p. 33) the so-called internal experiencer argument can be realized either as subject (cf. 1a) or as direct object (cf. 1b) at S-structure without implying change of theta role, i.e., the Experiencer Role is not affected. This means that change of case does not necessarily imply change of role or change in meaning. The question arises why the Russian language has at its disposal two different syntactic constructions, if they do not differ with respect to meaning. Furthermore, can it be true that both the nominative and the accusative may express the Experiencer Role, which is traditionally associated with the dative case? We believe that it is not possible for two different cases to carry exactly the same role.

Another but related problem is connected to the so-called Theta Criterion (see $2 \mathrm{a}$ and $2 \mathrm{~b}$ ).

a. Ona xorošo rabotala v mužskom kollektive.

'She worked well in a male environment'.

\footnotetext{
${ }^{2}$ For a detailed survey of GB case theory, see Malchukov \& Spencer 2008.
} 
b. Ej xorosho rabotalos' v mužskom kollektive.

'She worked well in a male environment'.

The Theta Criterion states that each argument bears one and only one theta role, and that each theta role is assigned to one and only one argument. This means in plain terms that it is impossible to assign two or three semantic roles to a subject, object or an adverbial and that a certain semantic role can only appear in one argument in a single clause. The type of alternation between (2a) and (2b) is discussed by Franks (1995, p. 364 ff.) and is explained as a change from verb (Agent, $\langle\emptyset\rangle$ ) to verb-sja (Experiencer, $\langle\emptyset\rangle$ ), i.e., the dispositional reflexive absorbs the nominative (the Agent) and modalizes it. The real semantic distinction between (2a) and (2b) forces us to reconsider the first part of the Theta Criterion. Already in (2) it turns out that it is necessary to assign two different roles to the external argument: (1) Locator and (2) Actor. In other words, (2a) has the following meaning: "While being in a male environment she worked well". In (2b) it is necessary to assign three different roles to the dative noun: (1) Locator, (2) Actor, and (3) Experiencer - the latter role explains the dative case: "When being in a male environment and while working there she felt fine". This strongly suggests that an NP can be assigned more than one theta role and that change of case in different syntactic constructions may be an expansion of case roles assigned at another level. It is, however, crucial to point out that the expansion goes in one direction: from pure / physical existence to modal / psychological existence.

In GB Theory case is almost reduced to phrase structure, i.e., it has little to do with semantics. Due to that, there is no distinction between morphological case and abstract case. All languages are described in terms of Universal Grammar, which - as we see it - cannot but obscure important differences in nature between languages, for instance, between Russian and English. ${ }^{3}$

\subsection{The Cognitive Linguistics approach}

Langacker proposed the so-called stage model, which takes a dominant part in semantics and syntax (Langacker 1991, p. 382 ff.). People organize scenes into participants and settings and segment clusters into discrete events. Different case markers profile specific parts of the action chain, which according to Langacker has a head (Agent) and a tail (Patient). The canonical event model consists of an action-chain head corresponding to Agent and an action-chain tail corresponding to Patient - both are so-called basic-level categories (cf. Rosch 1977; Lakoff 1987).

Janda 1993's theory of Russian case is specifically inspired by Wierzbicka's analysis of the Russian instrumental (1980) and the Polish dative (1986), but with respect to the overall theory she adheres to Cognitive Grammar as it is formulated by Lakoff (e.g., 1987) and Langacker (e.g., 1991), i.e., as a sort of reaction against any theory that treats semantics in a highly formal and abstract way (cf. Jakobson) or as if it were syntax (cf. GB theory). She, however, replaces Langacker's Agent and Patient by 'nominative' and 'accusative', respectively. ${ }^{4}$

Under case meaning Janda distinguishes 'core meaning', which is identical to the overall notions of prototype / gestalt and represents something universal, and 'submeanings', which are

\footnotetext{
3 Note that Pesetsky (2013) treats case markers within nominal phrases as part-of-speech categories. The interesting thing about this is that within this new framework he treats the genitive as indicating a nominal stem, while the nominative, accusative and oblique cases add something to that stem by being affixes of the category of determiners, verbs and prepositions, respectively. This is in contrast with Jakobson (1936), but is congruent with our view if we only consider the genitive within what we call the mini case system.

${ }^{4}$ For a detailed survey of case theory in Cognitive Grammar, see Malchukov \& Spencer 2008.
} 
language-specific extensions of core meaning. Janda's concepts look like modernized versions of Jakobson's principal and particular meaning, but she considers case meanings to form a continuum. She emphasizes that it is not by accident that a certain verb governs a certain case this is directly opposed to the GB view. She calls for a unified description of pure case and prepositional case - just as Jakobson did - but she maintains that prepositional case takes only a peripheral part in the semantic network of a certain case. Later, we shall provide evidence for the fact that prepositional case and pure case are equally important for the development of oblique cases, but not for direct cases because their domains are different. However, it seems to be the case that the meaning of the accusative in the pure case system has been strongly influenced by its function in the prepositional system.

In her treatment of the Russian dative and instrumental Janda takes her starting point in the general concepts of location and movement and uses them in her perceptual account of the two cases. The core meaning of the dative case rests in the indirect object function (cf. 3a) with two local submeanings, viz. governed dative (cf. 3b) and impersonal dative (cf. 3c) both derived from the indirect object construction in (3a):

a. Ljudmila dala Ivanu cvetok.
'Ljudmila gave Ivan a flower.'

b. Ivan pomogaet mame.

'Ivan helps his mother.'

c. Mne xolodno.

'I am freezing (lit. cold).'

The case meaning of dative is a combination of the meanings of the nominative and the accusative. The combined role attributed to the dative case equals a Recipient and a Counteragent, i.e., a person who suffers by receiving something, but simultaneously is capable of doing something on his own. It is important to note that the local submeanings in (3b) and (3c) are explained as being results of the loss of the accusative in (3a) and of the nominative in (3b) they are thus linguistic manifestations of Langacker's incomplete action chains (Langacker 1991, p. 333).

Janda's claim that the core meaning of the dative rests in the indirect object construction (cf. $3 a$ ) and that (3b) and (3c) are syntagmatic variants of (3a) can hardly be justified. First of all, the dative and short form construction in (3c) is acquired earlier by the Russian child than the indirect object construction (cf. Gvozdev 1961 [1949]). Secondly, (3c) is more simple in meaning than (3a): it represents a state description and not an action description (cf. DurstAndersen 1996). Janda reads (3c) as "An action takes places on a dative in a setting. The dative retains independent status" (1993, p. 55), and seems to ignore that there is no action at all, nothing takes place, and nothing is happening to the person in the dative case (in contrast to $J a$ merznu 'I am freezing / shivering'). Her analysis seems to be based on the internal situation referred to: there must be something that makes the person feel cold, i.e., something is acting on a dative in a setting. Besides, it should be emphasized that (3b) and (3c) are intransitive constructions, whereas (3a) is transitive. The two intransitive constructions are explained by Janda as detransitivized variants of the transitive construction in (3a) which cannot be true either, since they are intransitive by birth and could not be transitive according to the Russian language (cf. below). ${ }^{5}$

It seems to be the case that Janda has not said anything substantial about case roles in Russian, i.e., what a certain case form means in itself, but has said much about participant roles,

\footnotetext{
${ }^{5}$ For further details, see Janda \& Clancy 2002.
} 
i.e., those roles which are carried by persons or things in real situations. In the following, we shall try to separate these two important levels. One thing is general, universal background knowledge of actions and their participants, another thing is how the Russian language contributes to all this by making distinctions and contrasts that may throw new, concrete light on the various abstract phenomena. At the same time, we acknowledge the perceptual approach to case taken by Cognitive Grammar and Janda. It will be demonstrated that the mini system of Russian case involves various figure-ground relationships, whereas the oblique case system involves three different, but nevertheless, interrelated viewpoints corresponding to three different percepts each with its own reflexes. In short, the Russian case system seems to be entirely based on perception. If this is true, then we need a new framework and new concepts.

\subsection{The Columbia School semiotic approach}

The latest contribution to the study of Russian case is Beytenbrat's book (2015) that is based on the Columbia School (CS) theory and therefore also influenced by Jakobson. She insists on drawing a sharp distinction between case as a 'sign' which is composed of a signal and its 'invariant meaning', and case as a 'message' which is motivated by the invariant meaning, but is extralinguistic in nature and conveyed by a particular case form in a particular context. Inspired by the CS case systems elaborated for other languages (Diver 1974, 1981; Zubin 1979; Tobin 1985; Diver \& Davis 2012) Beytenbrat points out, in line with Jakobson (1936), that every language should be examined on its own premises. On that ground, she rejects the proposed analyses as unsuitable for Russian as to the semantic substance that constitutes the invariant meaning of a particular case.

According to Beytenbrat (2015), the Russian case system consists of six cases, i.e., six signs with six invariant meanings. They are divided equally into two classes each forming their own grammatical system, called the System of Contribution and the System of Involvement. The nominative, dative and accusative form the central System of Contribution and according to their level of saliency in an event they are ranked as HIGH CONTRIBUTOR, MID CONTRIBUTOR and LOW CONTRIBUTOR, respectively. The genitive, instrumental and locative form the peripheral System of Involvement and according to type of information added to the System of Contribution they are ranked as DIRECT INVOLVEMENT, INDIRECT INVOLVEMENT and MORE INDIRECT INVOLVEMENT, respectively. This is a reminiscent of Jakobson's central and peripheral cases. It is stressed that from the point of view of CS theory only one meaning for each case is acceptable, and that the System of Contribution should be strictly defined in terms of saliency without resorting to additional features like 'agent-like quality', 'focus' or 'control', which are used by other CS scholars. However, in this respect Beytenbrat's own treatment of Russian case shows lack of consistency because she repeatedly makes use of all these terms while trying to substantiate the invariant meaning of the Russian case forms within the System of Contribution. For instance, she defines the invariant meaning LOW CONTRIBUTOR, i.e., the invariant meaning of the accusative, as "the least salient or the least agent-like contributor" (2015, p. 61), upholding at the same time that "the System of Contribution is defined in terms of saliency and not agentivity" (2015, p. 55).

Let us take an illustrative example in which she explains the difference between the accusative and the dative on the basis of their invariant meanings in identical utterances:

$$
\begin{aligned}
& \text { a. Ona emu prostila } \\
& \text { she-nom he-dat forgave } \\
& \text { 'She forgave him' }
\end{aligned}
$$

b. Ona ego prostila

she-nom he-acc forgave 
Beytenbrat claims that in (4a) "the forgiving is directed towards him (dat), which turns him into the MID CONTRIBUTOR", while in (4b) "he (acc) undergoes the forgiving, which implies that him is a LOW CONTRIBUTOR". This type of labelling and reasoning can hardly be called comprehensible or illustrative, since in (4b) with the accusative it is the the person in question that is forgiven for what he did, whereas in (4a) with the dative the person is not forgiven directly - it is his behaviour or conduct that is forgiven, which at the same time releases him of any kind of guilt or obligation.

Besides, Beytenbrat seems to mingle different approaches, for instance, by using Janda and Clancy 2002, when she tries to spell out the semantic substance of the Russian cases. This is very clear in the case of the dative (2015, p. 64). Moreover, in her overview of 'messages', Beytenbrat merely lists uses of each Russian case form borrowed from Wade 1992 and monographs on Russian case without differentiating the linguistic levels they belong to.

When dealing with prepositional case, Beytenbrat mantains that "each preposition has its own invariant meaning which must be compatible with the invariant meaning of the case it "governs"” (2015, p. 108). Her primary purpose is to demonstrate this compatibility, but what she actually does is to show how prepositions are associated with 'messages', i.e., numerous and quite diverse uses of a particular case form.

It appears that Beytenbrat's attempt to render a comprehensive description of the Russian case system based on invariant meaning has run into the well-known problem of having difficulty with adhering to the declared criterion in a consistent way and with keeping one linguistic level apart from another.

In this paper, we propose a new semantic approach to the Russian case system which appears to be able to avoid the majority of all the above mentioned flaws and shortcomings. It will, for instance, be shown that it is possible to sharply distinguish between the case meaning of a preposition and its lexico-semantic meaning. This allows us to describe and explain prepositional phrases involving the same case form (e.g., the genitive), but different prepositions (e.g., $s$ 'from', $o t$ 'from', and $i z$ 'from') that point to different places in the syntactic structure of the sentence. In other words, the sign value of a prepositional phrase does not seem to be an inherent part of the case marker, but of the preposition itself.

\section{The semantic system of pure case}

\subsection{Russian case as the nominal equivalent to mood}

The Russian system of pure case consists of six cases: nominative, accusative, genitive, dative, instrumental and vocative. The locative has no place in this system, since it is used only in connection with prepositions ${ }^{6}$. Just as the Russian category of mood is divided into subcategories, viz. the indicative, imperative, and subjunctive moods, the Russian category of case can be divided as well. However, neither modern Russian linguistics ${ }^{7}$, nor modern general linguistics provide a corresponding division of case into hierarchically organized subcategories; normally, cases are listed as if they were equal in $\operatorname{rank}^{8}$. Some Russian linguists state though that

\footnotetext{
${ }^{6}$ Linguists identify from 4 to 14 cases in Russian depending on the goal and approach of their study (cf. Uspenskij 1957; Padučeva 1960; Zaliznjak 1967; Mel'čuk 1997; see also Comrie 1986), but the generally accepted number is 6.

${ }^{7}$ For a comprehensive overview of the earlier Russian tradition, see Klobukov 1986.

${ }^{8}$ Attempts to devide the Russian case system into subcategories on the basis of diverse criteria were made by Stepanov (1968) and Mel'čuk (1997). In this connection it should be noted that according to Mel'čuk Russian cases fall into two underlying types - syntactic and semantic ones (cf. Kuryłowicz 1949), and from his point of view it is only the latter that have some meaning, while the former merely express syntactic roles of the noun (see also Kustova 2011).
} 
the nominative stands out from the other cases. In conformity with the old "school grammar" tradition which goes back to the Greek and Latin tradition they talk about the nominative as a direct case opposed to indirect cases (cf. Lat. casus rectus vs. casus obliquus), but they do not elaborate this idea any further (cf. Knorina 1996 [1981]; Klobukov 1986; Šeljakin 2001, p. 39 ff.; Voejkova 2011). On the other hand, some other linguists almost compeletely disregard the nominative in their description of the Russian case semantics (cf. Popova 1970).

We shall treat the distinction between direct and oblique cases in Russian as a semantic distinction, which has formal consequences. Russian does not distinguish between the nominative and all the other cases, but between the nominative and the accusative, on the one hand, and all the other cases, on the other hand. This appears from the fact that both the nominative and the accusative cases are subject to the so-called genitive of negation rule (Babby 1980; Franks 1995), behave identically with respect to numerals and, all other things being equal, share the same morphological endings.

In Russian, we see mood as the verbal equivalent to case or case as the nominal equivalent to mood. They are both relational-semantic categories and thus presuppose two other categories in order to function. Mood presupposes the existence of a certain verbally copied situation signalled by the specific verb combined with its aspectual form, on the one hand, and the existence of a certain original situation signalled by the category of tense, on the other. Tense places the original situation referred to in a past, present or future world. In short, the Russian verb represents a verbally copied situation, while tense places the original situation in a specific time world. The function of mood is to indicate whether or not there is a relation of equality between the copied and the original situation. If there is a relation of equality (signalled by the indicative as a direct mood form - a 'modus rectus', cf. Rus. prjamoe naklonenie), then there is a situation in external reality (On prišel včera 'He came yesterday'); if there is a lack of equality (signalled by any of the two oblique mood forms, cf. Rus. kosvennoe naklonenie), then there is no situation in the real world to refer to. Thus, the situation shown to the hearer was copied from an imagined world, not from the real world. The subjunctive mood states that this lack of equality should be understood as something that cannot be changed (On prišel by včera 'He would have come yesterday'). The imperative mood treats the lack of equality as something that has to be changed (Prixodite zavtra! lit. 'Come tomorrow!'). (For a detailed description of the hierarchical structure of the Russian verbal system, see Durst-Andersen 2011, pp. 187-191).

If case is a relational-semantic category, then it must also presuppose the existence of two other nominal categories in order to function. Case presupposes the existence of a certain verbally copied entity signalled by the noun in combination with the category of animacy / inanimacy, on the one hand, and the existence of a certain real person or thing signalled by the category of number, on the other. Number places the entity referred to in a real situation (cf. Durst-Andersen 2011, p. 191 ff.). We thus argue that a Russian noun represents a verbally copied entity, be it a person or a thing, whereas number places a person or a thing in a real situation.

The nominative and the accusative function just as the indicative mood, i.e., as direct cases: they denote equality between the copied entity and the real person or thing and thus signal that the person or thing denoted by the noun is indeed present in the de facto situation referred to by the verb. In short, the nominative and the accusative signal local reference (Mama doma 'Mother is at home'; Muž podaril žene cvety 'The husband gave flowers to his wife'). If we translate this into the language of perception, we get the following: the nominative noun and the accusative noun will always correspond to a figure (cf. mother; cvety) on a ground (cf. doma; žene). In connection with state verbs (Dom viden vsem 'The house can be seen by everyone'), the nominative will correspond to a stable figure; in connection with activity verbs (Oleg igraet $v$ tennis 'Oleg is playing tennis'), the nominative will correspond to an unstable figure. But, if the nominative and the accusative cases appear in the same sentence, then the two types of figures become specified: the nominative will always correspond to an unstable figure, while the accusative will correspond to a stable figure (Muž podaril žene cvety 'The husband 
gave flowers to his wife': The husband (nom) did something so that the flowers (acc) exist with his wife).

All other cases function as non-indicative forms, i.e., as oblique cases: they denote nonequality between the verbally copied entity and the original person or thing referred to - they signal non-local reference. If we translate this into the language of perception, we get the following: The genitive noun (Mamy doma net lit. 'There is no mother at home'; On ne daril mame cvetov 'He didn't give flowers to his mother') and the vocative noun (Mam! 'Mommy!') will always point to a picture in which there is no figure. This means in plain terms that the person named Mommy and the flowers are not present in the situation referred to. The same applies to the two other uses of the genitive: Mama vypila čaju 'Mother had some tea' and Ljudej sobralos'! 'So many people have gathered here today!'. In the former case, we are dealing with a certain quantity that cannot be measured as one or two cups, and in the latter case, we are dealing with so many people that they cannot be counted. In both cases, it is impossible to see the genitive noun as depicting separated figures on a ground. In this way, one could argue that the notion of local reference is replaced by the notion of global reference. (For a detailed description of the so-called direct vs. oblique subject split and the so-called direct vs. oblique object split, see Durst-Andersen 2002; 2011, pp. 193-197).

\subsection{The vocative as the nominal equivalent to the imperative}

Since the vocative case normally is not part of the existing theories of Russian case, we deal with it in a separate paragraph. The vocative case always manifests itself in the same way. It occurs with animate nouns in an utterance without any finite verb and is signalled by intonation pattern II (IK-2), e.g., Len!, Lena!, Elena Vladimirovna!, Kollegi! 'Colleagues!' (for intonation patterns, see Bryzgunova's system in Švedova 1980). Traditionally, what we call the vocative case is not treated as a proper case form because it has mainly been associated with a zero form of animate nouns ending in -a (Len! Lenk! 'Lena!', Saš! 'Sasha!', Vit'! 'Vitja!', Gal'! 'Galja!', Mam! 'Mommy!', Pap! 'Daddy', Bab! 'Granny!', Synul’! 'Son!', Dočk! 'Daughter!', Rebjat! 'Guys!', Devčat! 'Girls!', Tet' Len! 'Auntie Lena!', Psin! 'Dog!') and because it has no syntactic function opposing it to other case forms (cf. Yadroff 1996; Danièl' 2008, 2009; Corbett 2008; Daniel \& Spencer 2009; Andersen 2012; for a different view in favour of the vocative case in its own right, although only in connection with the zero form, see Klobukov 1986; Bilý 1990; Mel'čuk 1997, p. $340^{9}$ ). This implies that case is solely grounded on syntactic functions, which contradicts our view on case in Russian as the nominal equivalent to mood. Seen from this perspective, the vocative case is the nominal equivalent to the imperative mood (cf. DurstAndersen 1996). Besides, our view on the vocative is based on data from early language acquisition. These data show that it is acquired together with and opposed to the nominative and parallel to the imperative (cf. Gvozdev 1961 [1949], p. 162 ff., Cejtlin 2000, p. 86, 101, 139; Pupynin 1996; for further evidence, see Kiebzak-Mandera 2000; Gagarina \& Voeikova 2009, p. 192). It functions exactly as the imperative: it treats the lack of equality between what is named and what is the case in the situation refered to as a matter to be changed. In other words, the speaker requests the hearer's local reference: he wants the hearer to come into his picture (Saś! in the sense of 'Come here!') or he wants himself to be part of the hearer's next picture (Saš! in the sense of 'Look at me!'). Note that the vocative case and the imperative mood share zero endings and intonation pattern - this can and should be taken as being a symptom of their shared content. We emphasize that the vocative case is highly frequent, although inherently defective, since it cannot be applied to inanimate entities, e.g., *Stol! '*Table!', *Sumk! '*Bag!' ${ }^{10}$

\footnotetext{
${ }^{9}$ Athough Zaliznjak (1973) does not include the vocative case in his list of 14 Russian cases, he as well considers the existence of 'incomplete cases' (Rus. nepolnyj padež) in human languages to be quite common and natural, and within the framework of his analysis the Russian vocative should be a member of the paradigm in its own right.

${ }^{10}$ It should be noted though that other languages use the vocative in connection with inanimate nouns. This applies,
} 
Moreover, one cannot expect it to be part of a system of syntactic functions due to the fact that it appears in utterances without a finite verb. We admit that there is a distinction between the zero form and the non-zero form used with intonation pattern II. It seems to be the case that the nonzero form can be used in any type of discourse, whereas the zero form is used only in private discourse. In that respect Len! vs. Lena! should be compared to mamina sumka vs. sumka mamy 'Mommy's bag' as well as my s Lenoj vs. Lena i ja 'Lena and I'.

\subsection{The genitive, dative and the instrumental as oblique cases}

The remaining three cases, i.e., the genitive (in the uses where it does not enter into opposition with the nominative or the accusative), the dative and the instrumental, function as a broad subjunctive mood: they treat the lack of equality as a matter of fact, i.e., the person or thing named by one of these three oblique cases is not treated as absolute entities, but as relative entities. What matters is not whether or not they are present or absent in the de facto situation referred to by the verb or whether or not they can be treated as figure on a ground. What matters is the viewpoint which is applied by the observer who is located at some point - being figure on a certain ground. In the following paragraphs, we shall examine the three viewpoints corresponding to the genitive, the dative and the instrumental cases. In short, when we leave the Russian mini case system, we leave the notion of absolute existence and enter into the realm of relative or modal existence.

\subsection{Summing up}

As should be evident, the major dividing line in this new system cuts across the Jakobsonian one, since in the so-called mini case system the genitive is directly opposed to the nominative and the accusative. In that way, it becomes comprehensible why the nominative as well as the accusative are substituted by the genitive under certain conditions. The nominative and the accusative, on the one hand, and the vocative and the genitive, on the other, thus comprise a central system which is determined by the factor local vs. non-local reference in objective reality: if there is local reference, i.e., somebody or something exists on location (we talk about pure or absolute existence), then the direct cases, i.e., the nominative and the accusative, are used; if there is no local reference, i.e., there is nobody or nothing to refer to (no pure existence), neither the nominative nor the accusative can be used. If non-local reference is understood as a matter to be changed, then the vocative is used (Len!, Lena!); if non-local reference is understood as a matter of fact, then the genitive is used (Leny segodnja net 'Lena is not here today', lit. 'There is no Lena here today'). If somebody or something exists on some location, but one is not concerned with their pure existence, but rather with their modal or relative existence, then either of the oblique cases is used.

\begin{tabular}{|c|c||}
\hline DIRECT CASES & OBLIQUE CASES \\
\hline NOMINATIVE AND ACCUSATIVE & $\begin{array}{c}\text { GENITIVE AND VOCATIVE } \\
\text { DATIVE AND INSTRUMENTAL }\end{array}$ \\
\hline
\end{tabular}

Table 1 Major classes of Russian case 
If we disregard the "absolute" use of the genitive case where it replaces the nominative and accusative cases ${ }^{11}$, the genitive, dative, and instrumental cases all involve a relative or correlative viewpoint, i.e., each of them presupposes an object of comparison. Thus that the genitive and the vocative are opposed to the nominative and the accusative in their "absolute" use (we could name this specific use of the genitive case 'genitive 1' or the absolute genitive), while the genitive alone is opposed to the dative and the instrumental in its "relative" use (here specifically called 'genitive 2' or the relative genitive).

\subsection{The genitive case}

\subsubsection{The extrovertive viewpoint}

We shall argue that the genitive involves what we call an extrovertive viewpoint, i.e., it denotes a perceptual relation or a perceptual direction from something near, A, to something distant, B. Its starting point is A, and B, the object of comparison, is its terminal point. The observer (marked (X)) is located in A and views B from his vantage point, A (marked x $\}$ ). In order to apply the extrovertive viewpoint, location point and vantage point must coincide:

\section{(X) $\mathbf{x}\} \mathbf{A}>\mathbf{B}$}

Fig. 1 The extrovertive viewpoint

Before deriving physical and logical concepts from this percept we shall take a look at Russian verbs that verbalize the extrovertive viewpoint.

\subsubsection{Verbs denoting extrovertive direction}

Verbs which take the genitive because they denote an extrovertive direction can be divided into two natural groups. The first group consists of verbs which profile the terminal point of the extrovertive direction. This means that what is near, A, is left out of consideration, and the entire focus is on the distant, B, which then functions as an Objective in the military sense of the word. This can be illustrated in the following way:

\section{Dostignut' (dostič') / dostigat' B

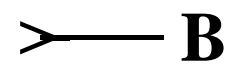

Fig. 2 Reaching an Objective

Apart from the above-mentioned action verb'12 dostignut' (dostič') / dostigat' 'reach' the group includes dobit'sja / dobivat'sja 'reach, get', doždat'sja / dožidat'sja 'wait until, get at last / wait for', doiskat'sja / doiskivat'sja 'find, find out/seek', domogat'sja (ipf) 'strive for, ask for', and doprosit'sja / doprašivat'sja 'get smth. by begging'. As it appears, all these verbs include the prefix $d o$ - which should be taken as a sign of their common denominator "reach" (in connection with the perfective aspect) or "seek" (in connection with the imperfective aspect). Let us take some illustrative examples:

\footnotetext{
${ }^{11}$ There exists a very extensive literature on the genitive of negation in Russian, one of the most well studied case alternations. For references and comprehensive survey of the state of the art in this area, see Partee et al. 2012; Padučeva 2013, pp. 82-192; Zel'dovič 2012, pp. 366-471; Harves 2013.

${ }^{12}$ For a short examination of the verb classification used here, see Durst-Andersen \& Lorentzen $2015 \mathrm{~b}$.
} 
a. Vojska dostigli važnogo rubeža. ${ }^{13}$

'The troops reached an important objective.'

b. Japonskie učenye dobilis' vpečatljajuščix uspexov v klonirovanii životnyx.

'The Japanese scientists achieved impressive results in the cloning of animals.'

c. Ona doždetsja okončanija spektaklja.

'She will wait until the end of the show.'

d. On tak i ne doiskalsja pravdy o smerti brata.

'He has never found the truth about his brother's death.'

e. Vsju svoju žizn’ on domogalsja vlasti.

'All his life he coveted power.'

f. My ele doprosilis' u nee deneg na bilet.

'We only with difficulty managed to get money for the ticket from her.'

If we compare the examples under (5) with Figure 2, it should be evident that what is called B is put in the genitive case.

The second group of verbs behave quite in the opposite way. They profile the starting point of the extrovertive direction and leave out the terminal point as should appear from the following figure:

\section{Izbežat' / izbegat' A}

\section{$\mathbf{A}$}

Fig. 3 Avoiding something or somebody

All the verbs in this group have underlyingly the component "avoid" whereby we can speak of the Distanced Role. In other words, the object is put in the genitive because it functions as the Distanced Role: the agent tries to get out of contact with what is near, A, and in that way A becomes distant. Apart from the above mentioned action verb izbežat' / izbegat' 'avoid' the group includes state verbs like bojat'sja 'be afraid of' (which, however, prefer the accusative in connection with individuals, cf. On boitsja mamu 'He is afraid of his mother', presumably because she demands local existence), opasat'sja 'fear', stesnjat'sja 'be shy', and stydit'sja 'be ashamed of', activity verbs like bereč'sja 'beware', gnušat'sja 'shun', storonit'sja 'keep away from', and čuždat'sja 'avoid somebody's company', and action verbs like ostereč'sja / osteregat'sja 'take care of, beware' and ispugat'sja / pugat'sja 'be frightened of'. Let us take some illustrative examples:
a. Ona boitsja temnoty.
'She is afraid of the dark.'
b. Beregis' poezda!

\footnotetext{
${ }^{13}$ The examples which are not provided with references are our own - PDA \& EL. Unless otherwise indicated, examples from the Internet have been last accessed on 18 March 2016.
} 
'Beware of trains!'

c. Ona gnušaetsja lži.

'She won't have anything to do with lies.'

d. On vsegda izbegaet trudnostej.

'He always avoids any kind of trouble.'

e. Devočka pugaetsja malejšego šoroxa.

'The girl is afraid of the slightest rustle.'

f. Policija opasaetsja novyx besporjadkov.

'Police fears new riots.'

g. Vse požilye ljudi osteregajutsja prostudy.

'All elder people try to avoid catching a cold.'

h. Naša novaja sosedka storonitsja neznakomyx ljudej.

'Our new neighbour avoids people she doesn't know.'

i. Ix četyrexletnjaja doč' stesnjaetsja vzroslyx.

'Their 4 years old daughter is shy with adults.'

j. Ona stala čuždat'sja svoix podrug.

'She has begun to avoid the company of her girlfriends.'

The fact that the two groups highlight respectively the near, A, and the distant, B, stresses the importance of the extrovertive viewpoint itself. In other words, all verbs that verbalize the extrovertive viewpoint take the genitive irrespective of choice of focus.

\subsubsection{The physical relation of separation}

If one $(\mathrm{X})$ is located at $\mathrm{A}$ and views $\mathrm{B}$, which is distant, from the point of view of $\mathrm{A}$, which then is near, B is in fact separated from A. In that way the extrovertive viewpoint entails the relation of separation, i.e., a special kind of relative existence, which says that B is separated from A in a physical sense of this notion, i.e., there is a gap between A and B (the dynamic variety will be exclusion):

\section{[A] [B]}

Fig. 4 The relation of separation

If this is true, we are in fact claiming the opposite of what is normally believed. It is a general belief that the genitive is tied up with possession (cf. Cienki 1995; Janda \& Clancy 2002, p. 125; Rakhilina 2004; Beytenbrat 2015, p. 84), which seems to be the opposite of separation. We do not deny that people connect the genitive with possession, but we deny that they do it because the genitive has possession as its grammatical meaning. The genitive itself assigns non-local reference and at the same time involves the viewpoint from something near to something distant, i.e., what we named an extrovertive viewpoint. This appears from the following examples:

a. On živet v kvartire brata. 
'He is living in his brother's apartment.'

b. On živet v / na kvartire u brata.

'He is living together with his brother in his apartment.'

In (7a) with the pure genitive there is no local reference, i.e., his brother is not present in the situation referred to. (7b) with the preposition $u$ is an instance of the general rule that all prepositions presuppose local reference and therefore we get the meaning near distance (see below). It might be true for other case languages that the genitive case is related to possession, but in Russian the relation is purely superficial and belongs to what we prefer to call communicated content. The fact that not only linguists, but also Russian people feel a certain possessive-like relation in certain genitive contexts can be explained by the extrovertive viewpoint combined with a human being as starting point and a lack of dynamicity. If one says dom (Nom) brata (Gen) 'my brother's house', one in fact separates "house" from "all my brother's belongings" in order to focus one's attention on the house. What triggers the genitive form brata 'brother's' is not that "house" is included in the set of all his belongings, but that "house" has been removed, excluded and focussed upon at the expence of "brother". In other words, the genitive does not involve possession properly speaking, but due to the fact that exclusion presupposes inclusion, people attach the presupposed content to the genitive. That the genitive has nothing substantial to do with possession and that the relation of the genitive to possession is established not by language, but by people themselves whereby the relationship can be said to belong to communicated content, appears indirectly from the fact that what could be called the Russian variant of 'inalienable possession' (cf. Žurinskaja 1977; Herslund 1994) is linked to the so-called possessive adjectives (e.g., papin dom 'my father's house', mamin komp'juter 'my mother's computer', Alešina komnata 'Aleša's room', etc.). One will use the genitive if the speaker does not want to include the hearer into one's private world. By using the genitive the speaker as a matter of fact excludes the hearer from his private world (cf. DurstAndersen 2002).

\subsubsection{The logical relation of non-identity}

The fact that B is separated or is far from A (see Figure 5) can also be interpreted in logical terms whereby we arrive at the relation of non-identity: to state that B is logically separated from $\mathrm{A}$ is tantamount to saying that $\mathrm{B}$ is non-identical to $\mathrm{A}$. It is crucial to understand that when A enters into a relation of comparison to $\mathrm{B}$, it is not any $\mathrm{A}$ and any $\mathrm{B}$ which may be compared $A$ and $B$ must be members of the same category (in a relevant sense) in order to compare them with respect to a certain quality, be it height, thickness, cleverness, cheapness, etc. Out of two logical possibilities, the relation of comparison instantiates a non-identity in the genitive case:

\section{$\mathbf{A} \neq \mathbf{B}$}

\section{A dorože / deševle B}

Fig. 5 The relation of non-identity

If, for instance, $\mathrm{A}$ is non-identical to $\mathrm{B}$ with respect to price, then $\mathrm{A}$ is either more expensive or less expensive than B. In the case of separation and in the case of non-identity B will be in the genitive case due to the fact that B is the oriented part of the extrovertive viewpoint:

a. Ona vyše mamy.

'She is taller than her mother.' 
b. On tolšče syna.

'He is thicker than his son.'

c. Deti umnee roditelej.

'The children are smarter than their parents.'

In this way, we have succeeded in relating uses of the genitive case which are traditionally regarded as being completely unrelated (e.g., so-called adnominal uses and verbal uses).

\subsubsection{Reflexes}

Furthermore, we argue that the extrovertive viewpoint together with the relation of separation and non-identity is subject to further concretization when they meet other conceptual domains such as Space, Time, and Figurativity. We claim that the genitive has the following spatial, temporal and figurative reflexes:

Spatial reflex: Near Distance (static) - Removal (dynamic)

(9) a. Na obratnom puti my deržalis' levogo berega.

'On the way back we kept to the left side of the river.'

b. Otec lišil ego nasledstva.

'He was denied his inheritance by his father.'

Temporal reflex: Quantity (separated from moment of speech).

(10) Oni uezžajut v otpusk dvenadčatogo ijulja.

'They are leaving on holiday on the 12th of July.'

Figurative reflex: Cause.

(11) Serdečno-sosudistye zabolevanija javljajutsja glavnoj pričinoj smerti vo vsjom mire.

'Cardiovascular diseases are the leading cause of death worldwide.'

Note that one can only use the nominative in the following sentence type with temporal lexemes (včera, segodnja, zavtra):

(12) Segodnja - dvadcat' pjatoe oktjabrja.

'Today is the 25th of October.'

This is so because here there is a relation of equality between today and the date (i.e., Today $=$ 25 October). In all other cases, there is no such relation, and the genitive becomes obligatory. Note, however, that when writing a diary one can choose between two devices: either one can write the diary as if one is verbalizing what is happening today (in this case one writes dvadcat' pjatoe oktjabrja), or as if one answers the question "When did the events to be described below happen?" (in that case one writes dvadcat' pjatogo oktjabrja).

\subsubsection{Summarizing remarks}


Cognitive Linguistics deals with four basic conceptual relations among which 'separation' is treated as a purely spatial relation (a trajector from a landmark) with 'source' as its absolute counterpart (Langacker 1991). Both concepts are linked to the nominative, but not to the genitive. In Hjelmslev 1972 [1935-1937] we find the notion of éloignement 'removal', but it is used only as a direction. In the present work, we take our starting point in perception, i.e., a certain viewpoint (the extrovertive viewpoint). On the conceptual level, the perceptual notion of viewpoint is replaced by the notion of relation, which is said to have two manifestations: physical (separation) and logical (non-identity). These concepts are then said to have reflexes, e.g., if the concept of separation meets the domain of Space, then it will be specified as Near Distance (when we are dealing with a purely static relationship) or Removal (when we are dealing with a dynamic relationship). Reflexes can thus be said to correspond roughly to particular meanings within a single language. This can be illustrated by figure 6 (for different accounts of genitive constructions, see Timberlake 1986; Borschev \& Partee 1999; Rakhilina 2004; Raxilina 2008; Kuznetsova \& Rakhilina 2015, and references therein):

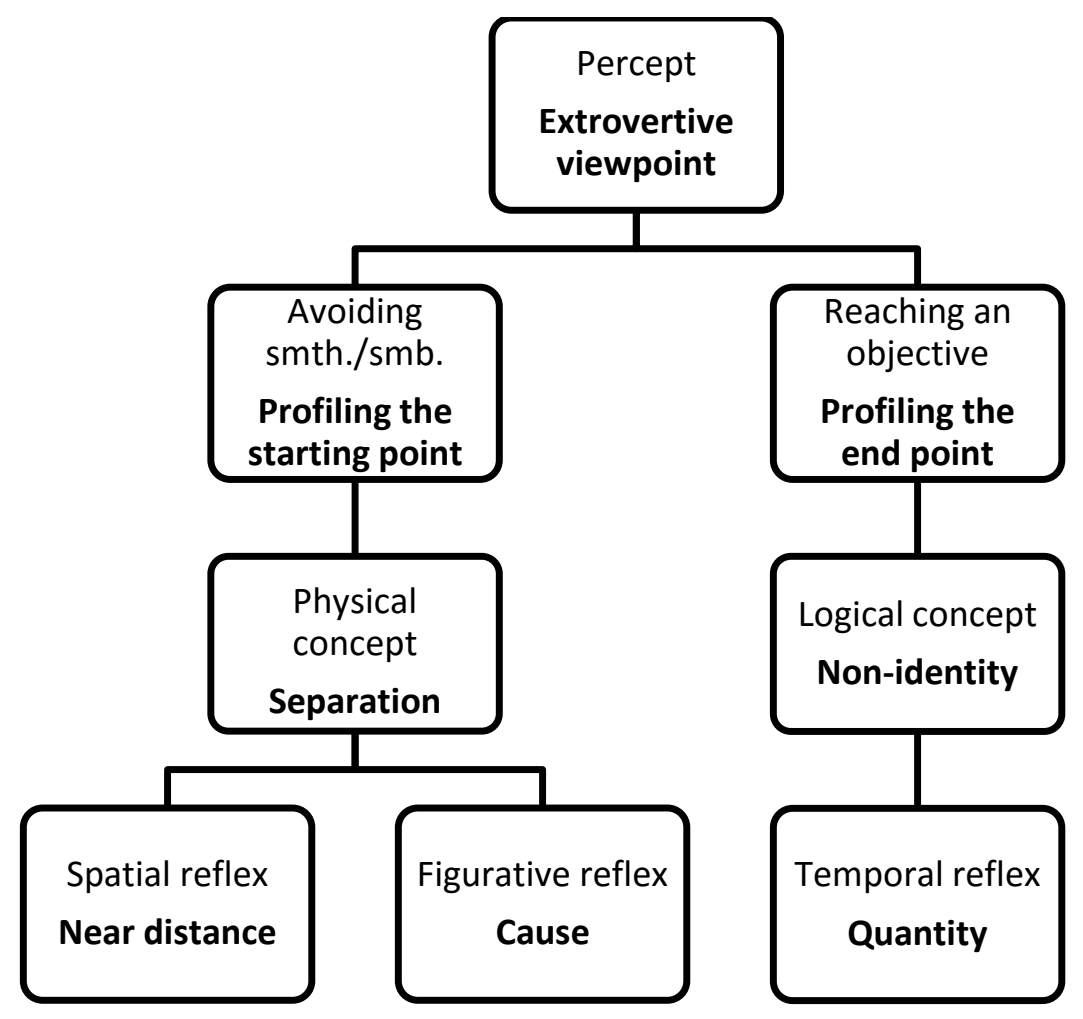

Fig. 6 The semantic hierarchy of the genitive case

\subsection{The dative case}

\subsubsection{The introvertive viewpoint}

The dative involves what we call an introvertive viewpoint, i.e., it denotes a perceptual relation or a perceptual direction from something distant, B, to something near, A. Since B is the starting point of the dative and $\mathrm{A}$ is its object of comparison, its terminal point, the dative and the genitive are converse cases:

$$
\text { (X) } \mathbf{A} \longrightarrow \mathbf{B}\{\mathbf{x}
$$


Fig. 7 The introvertive viewpoint

In this case the observer is located in A (this is always the case because this is exactly what defines what is near), but his vantage point is in $\mathrm{B}$, which is distant. In other words, in order to apply the introvertive viewpoint, location point (marked $(\mathrm{X})$ ) and vantage point (marked $\{\mathrm{x}$ ) must be different. Let us take a close look at those verbs that verbalize the introvertive viewpoint.

\subsubsection{Verbs denoting introvertive direction}

Verbs which take the dative case because they denote an introvertive direction can be divided into two groups. The first group consists of verbs which profile the terminal point of the introvertive direction. This means that what is near, A, is highligted at the expense of what is distant, B. This can be illustrated by the following figure:

Vyučitsja / učitsja čemu-l.(A)

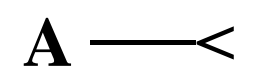

Fig. 8 Approaching a Goal

As should be evident from figure 8 and the description, the verbs denoting an approaching activity are converse to the verbs taking the genitive because they denote removal. The group includes action verbs like vyučitsja / vyučivat'sja 'learn', ustupit' / ustupat' 'concede, give in", poddat'sja / poddavat'sja 'yield', sdat'sja / sdavat'sja 'surrender; turn in'; activity verbs like molit'sja 'pray to', and others. Note that it is A, the so-called Goal Role, that is put in the dative case. Let us take some illustrative examples:

(13) a. Ego staršij syn vyučilsja plotnickomu remeslu.

'His elder son learned the craft of carpentry.'

b. Dver' poddalas' nažimu ego pleča.

'The door yielded to his shoulder.'

c. Oni nakonec ustupili ego trebovanijam.

'They finally gave in to his demands.'

d. On sam sdalsja policii i poprosil političeskogo ubežišča.

He turned himself in to the police and applied for political asylum.

c. Ona molitsja Bogu každyj večer.

'She prays to God every night'.

Whereas in all the above-mentioned examples of the first group of introvertive direction verbs the Agent is moving from B towards A, in the second group he is moving from A towards B simultaneously with B moving towards him:

Idti komu-l. (B) navstreču

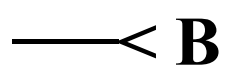


Fig. 9 Meeting something or somebody

In this case, it is B, the Counteracting Role, that is put in the dative case. The group comprises not only activity verbs like protivodejstvovat' 'go against' and soprotivljat'sja 'resist, oppose', and action verbs like pregradit' / pregraždat' 'block', vosprepjatstvovat' / prepjatstvovat' 'prevent', and predpočest' I predpočitat' 'prefer', but also state verbs like protivorečit' 'contradict' and predšestvovat' 'precede'. Note that the last mentioned group includes verbs which originally belonged to the class of activity verbs (hence the direction), but which now are used solely as state verbs. Let us take some illustrative examples from all the three verb classes starting with state verbs:

(14) a. Ėta teorija protivorečit praktike.

'This theory contradicts practice.'

b. Ego uvol'neniju predšestvoval krupnyj političeskij skandal.

'His dismissal was preceded by a major political scandal.'

c. On vsegda soprotivljaetsja vole otca.

'He always resists his father's will.'

d. Oppozicija vsjačeski protivodejstvuet politike pravitel'stva.

'The opposition strongly opposes the government's policy.'

e. Nepogoda prepjatstvovala ix svidanijam.

'The bad weather prevented them from seeing each other.'

f. Ona predpočla kar'eru sem'e.

'She preferred career over marriage.'

It is, of course, particularly interesting that the introvertive direction is connected to the (oblique) object and not to the subject of the verbs in question. Note that while the latter group can be said to have underlyingly "to go against the tide", the former group can be said to have underlyingly "to go with the tide".

\subsubsection{The physical relation of reception}

If one $(\mathrm{X})$ is located at $\mathrm{A}$, which is then near, and wants to view $\mathrm{A}, \mathrm{X}$ has to place his vantage point outside of A, in this case in B (see Figure 10). By looking at A, X's location point, from the point of view of $\mathrm{B}$, which is distant, $\mathrm{X}$ in fact embraces $\mathrm{B}$ and in this way incorporates $\mathrm{B}$ into A:

\section{(X) $[\mathbf{A}<\mathbf{B}]\{\mathbf{x}$}

Fig. 10 The relation of reception

If we view this strictly from the point of view of $\mathrm{B}$, one must say that $\mathrm{B}$ is received in $\mathrm{A}$. That is, when location point (marked $(\mathrm{X})$ ) and vantage point (marked $\{\mathrm{X}$ ) do not coincide, the viewer $\mathrm{X}$ embraces B in placing his vantage point at B while remaining physically at A. In this way, the introvertive viewpoint entails the relation of reception, i.e., a special kind of relative existence, which says that $\mathrm{B}$ is near to $\mathrm{A}$ in a physical sense of this notion without being in direct contact: 
This is the reason why all Recipients are put in the dative case:

(15) a. Kapitan prikazal soldatu otnesti komandiru vzvoda paket.

'The captain ordered the soldier to deliver the letter to the platoon commander.'

b. Emu trudno ugodit'.

'He is difficult to please.'

c. On vsegda vsem poddakivaet.

'He is a yes man.'

d. Členy sekty besprekoslovno podčinjajutsja svoemu lideru.

'Cult members blindly obey their leader.'

e. Skul'ptor pokazal prisutstvujuščim svoju novuju rabotu.

'The sculptor showed the guests his new work.'

f. Pervonačal'no Betxoven posvjatil svoju Tret'ju simfoniju Napoleonu Bonaparte.

'Beethoven originally dedicated the third symphony to Napoleon Bonaparte.'

g. Lavrovu prisvoili zvanie početnogo doktora MGU im. M. V. Lomonosova.

'Lavrov was awarded an honorary doctorate from Lomonosov Moscow State University.'

This is just a short extract from the long list of verbs that take an argument in the dative case because it bears the Recipient Role. In fact, it pertains to all indirect objects including inanimate entities which are said to bear a Goal Role (see, for instance, (17) below).

\subsubsection{The relation of experienced identity}

If we continue the line of thought from 2.6.3. where it was stated that B was received in A, we can say that the physical relation of reception entails the physical relation of proximity between $\mathrm{A}$ and $\mathrm{B}$, i.e., $\mathrm{B}$ is near to $\mathrm{A}$ without being in contact. If all this is transferred into the language of logic where A and B are compared, we get experienced identity, i.e., contiguity. We emphasize that we are not dealing with complete physical identity, where two objects are entirely alike, where B is one and the same with A. Thus, out of two logical possibilities the relation of comparison instantiates (experienced) identity in the dative case:

\section{A sootvetstvovat' $B$}

\section{$\mathbf{A} \approx \mathbf{B}$}

Fig. 11 The relation of experienced identity

It is obviously quite natural that adjectives like ravnyj 'equivalent to' and podobnyj 'similar to' also govern the dative case because they denote contiguity, i.e., experienced identity. In this way they resemble the state verb sootvetstvovtat' 'correspond to'. The same is true of the state verb ravnjat'sja 'equal', the activity verbs soputstvovat' 'accompany', sledovat' 'follow', 
akkompanirovat' 'accompany', podražat' 'imitate', and vtorit' 'repeat', and the action verbs nasledovat' 'inherit' and upodobit' / upodobljat' 'make alike', and others. Let us take some illustrative examples:

(16) a. Triždy četyre ravnjaetsja dvenadcati.

'Three multiplied by four makes twelve.'

b. V ètot raz našej komande soputstvovala udača.

'This time our team was lucky.'

c. Ona slepo sleduet mode.

'She blindly follows fashion trends.'

d. On akkompaniruet pevice na rojale.

'He accompanies the female singer on the piano.'

e. Rebenok podražaet staršim.

'The child imitates the adults.'

f. Žena vo vsem vtorit mužu.

'She repeats her husband in everything.'

g. Syn nasledoval otcu.

'The son succeeded to his father (jur.).'

h. Poèt upodobil molodost' vesne.

'The poet compared youth with spring.'

Note that the vast majority of verbs exemplify what we call the Model Role.

\subsubsection{Reflexes}

We argue that the various concepts derived from the original percept, become subject to concretization when they meet other conceptual domains. At this level the category of animacy / inanimacy plays a crucial role. If a language has a certain grammatical category, its content will necessarily emerge on the surface at other places. In other words, the introvertive viewpoint together with the relation of reception and experienced identity (contiguity) can be said to have the following reflexes when they meet the concepts of Space, Time, and Figurativity (Note that the temporal reflex manifests itself only in a prepositional phrase):

Spatial reflex: Goal (inanimate) - Recipient (animate).

(17) Ona učit detej russkomu jazyku.

'She teaches the children history.'

(18) Ona prepodaet studentam russkij jazyk.

'She teaches the students history.'

Temporal reflex: Repetition (the same every time).

(19) Deti prixodjat na zanjatija po subbotam. 
'The children attend classes every Saturday.'

Figurative reflex: Recipe or a Model to be followed.

(20) Poèt upodobil molodost' vesne.

'The poet compared youth with spring.'

\subsubsection{Summarizing remarks}

Cognitive Linguistics (Langacker 1991) operates with 'identity' and 'association', but they are taken as two different basic concepts, simply because 'identity' is defined as a hundred percent physical identity, whereas 'association' is defined as psychological proximity, i.e., contiguity. But none of them are connected to the dative case. The dative is linked solely to the active zone in the target domain. Hjelmslev (1972 [1935-1937]) operates with the notion approchement 'approaching', but it is used only as a direction. Here we have attempted to demonstrate that the dative case is tied to the introvertive viewpoint that is converse to the extrovertive one and presupposes it. The introvertive viewpoint has two conceptual counterparts: the physical relation of reception and the psychological (logical) relation of experienced identity (contiguity). These concepts are then said to have reflexes, e.g., when the concept of reception meets the domain of Space, then it will be specified as Goal (if we are dealing with an inanimate entity) or as Recipient (if we are dealing with an animate one). This can be illustrated by figure 12 which is interestingly enough a mirror image of figure 6 (for other accounts, see, e.g., Cienki 1995; Kustova 2012, and with particular emphasis on the so called "dative of possession" Levine 1986, 1990; Cienki 1993; Podlesskaya \& Rakhilina 1999; Šarić 2002; and references therein):

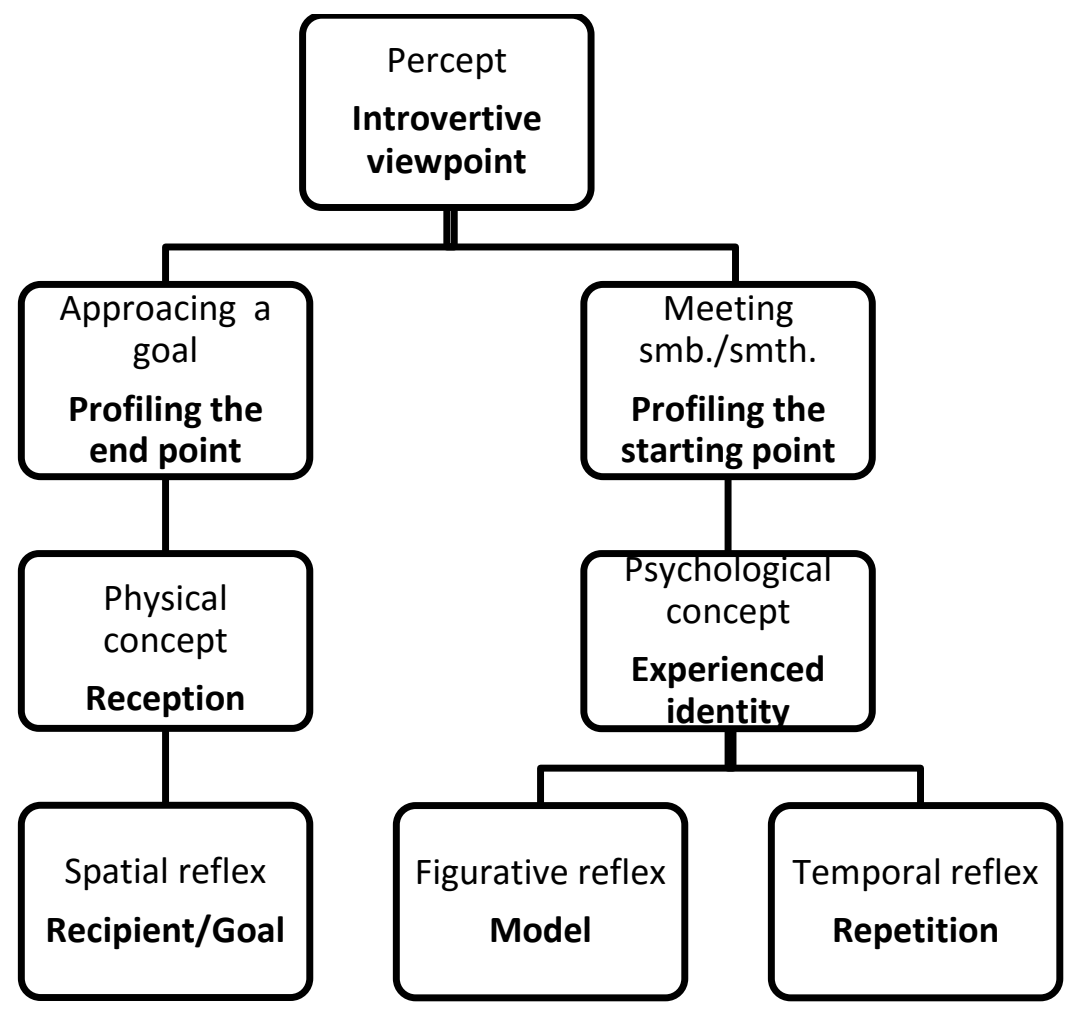

Fig. 12 The semantic hierarchy of the dative case

2.7 The instrumental case

\subsubsection{The correlative viewpoint}


The instrumental case can be said to presuppose the existence of the two other oblique cases, since its viewpoint is correlative, i.e., it denotes an interrelationship between something near, A, and something distant, $\mathrm{B}$. This means that one $(\mathrm{X})$ is located at something near, $\mathrm{A}$, but is viewing at the relationship between A and something distant, B, from an external point of view (x\}), i.e., from the point of view of totality. In other words, in this case too X's location and vantage point do not coincide, but in contradistinction to the dative vantage point, the instrumental vantage point is placed at an upper level or completely outside A and B. The result is that we leave the level of comparison where A and B are either identical or non-identical, and instead we enter another level, where $\mathrm{A}$ is incommensurable with $\mathrm{B}$, but nevertheless closely related to $\mathrm{B}$, and vice versa. This interrelatedness between something near, A, and something distant, B, can be depicted as in figure 13:

\section{(X) $\mathbf{A}><\mathbf{B}$ \\ $\{\mathbf{x}\}$}

Fig. 13 The correlative viewpoint

Before we look at the concepts that can be derived from this percept, we shall take a look at verbs, or rather syntactic constructions, which verbalize the correlative viewpoint.

\subsubsection{Verbs denoting a correlative viewpoint}

Let us look at the domain of Space where the correlative viewpoint of the instrumental case manifests itself as VIA, i.e., the spatial interpretation of the interrelatedness between something near and something distant:

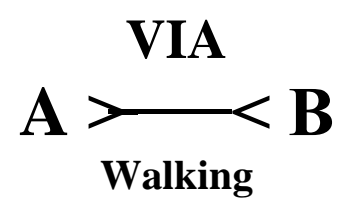

Fig. 14 Walking via something

An illustrative example of VIA would be (21a) which should be compared to (21b) and (21c):
a. Oni šli (sosnovym / *bol’šim) lesom.
'They walked through a (pine/*big) forest.'
b. Oni šli čerez les.
'They walked through a forest.'
c. Oni xodili po lesu.
'They walked around in a forest.'

Note that what we call an incorporated construction, viz. (21a), accepts only an attributive relative adjective, but not a qualitative one. What is then the difference between (21a) and the related constructions (21b) and (21c)? (21b) says that some people produced an activity of walking the direction of which went right through a forest. (21c) states that some people 
produced an activity of walking without any direction, but still within the limits of a forest. In (21a) the direction of motion is solely linked to the determinate verb of motion and has nothing to do with the instrumental noun. Lesom 'forest' manifests the meaning of VIA in its incorporated function, i.e., it modifies the activity itself: They produced (pine/*big) forestwalking activity. Place has become an inherent property of the activity. This takes us directly to the next paragraph.

\subsubsection{Integral part or inherent property}

There is only one genuine kind of interrelatedness, that of part-whole. The part-whole interrelationship between A and B may, however, be understood in two ways: either purely physically, whereby B is taken to be an integral part of A, or purely psychologically, whereby $\mathrm{B}$ is taken to be an inherent property of A:

\section{A $\mathbf{B}$}

Fig. $15 \mathrm{~B}$ is an integral part of $\mathrm{A}$

The meaning of inherent property is involved in those adjectives with short form that govern the instrumental case:

(22) a. Ėta strana bogata prirodnymi resursami.

'This country is (inherently) rich in natural resources.'

b. Ėta strana bedna prirodnymi resursami.

'This country is (inherently) poor in natural resources.'

If we take polnyj 'full' that takes the genitive or the instrumental case, the meaning of inherent property attached to the instrumental becomes even more obvious (cf. 23a and 23b).

(23) a. Dom naš vsegda byl polon vsjakimi dvojurodnymi brat'jami i sestrami. ${ }^{14}$

'Our house was always full of all sorts of cousins.'

b. Naš dom vsegda byl polon gostej, babuška gotovila mnogo vkusnoj edy. ${ }^{15}$

'Our house was always full of guests; grandma cooked a lot of delicious food.'

In (23a) the instrumental is used because "cousins" are an inherent property of a family house, whereas in (23b) the genitive is used because "guests" are not an inherent property of a family house.

The state verbs vladet' 'own' and obladat' 'possess', the activity verbs vedat' 'govern', verxovodit' 'play boss', zavedovat' 'manage', zapravljat' 'boss around', komandovat' 'command', pravit' 'rule', rasporjažat'sja 'to be in charge, manage, run', rukovodit' 'lead, manage', and upravljat' 'govern' and the action verb ovladet' / ovladevat' 'take into possession' take all the instrumental case because they deal with an inherent property. The inherent property, which is described in the entailment structure of activity and action verbs (cf. Durst-Andersen and Lorentzen 2015b) includes a certain institution that has been transferred to a certain person's jurisdiction:

\footnotetext{
${ }^{14}$ Fazil' Iskander Rasskaz o more (1962). Retrieved from: www.ruscorpora.ru.

${ }^{15}$ Lidija Vertinskaja Sinjaja ptica ljubvi (2004). Retrieved from: www.ruscorpora.ru.
} 
(24) a. Naš syn rukovodit finansovym otdelom krupnogo predprijatija.

'Our son leads the Finance Department of a major company.'

b. Našemu načal'niku nravitsja upravljat' ljud'mi.

'Our boss likes to manage people.'

c. Ol'ga Pavlovna sejčas zaveduet klubom.

'Olga Pavlovna is now in charge of the club.'

In other words, the department, people and the club are inherently possessed by respectively our son, our boss and Olga Pavlovna, and against this background they perform their respective activities. It is crucial to note that these verbs are used solely to give a characterization - they cannot be used to give a situation description (cf. Durst Andersen 2011).

The two possession-based state verbs, i.e., vladet' 'own' and obladat' 'possess', imply that somebody controls something: this something is at the possessor's disposal and can be used by him as a means:

a. On vladeet osobnjakom na beregu Černogo morja.

'He owns a mansion at the Black Sea.'

b. On obladaet bol'šimi sposobnostjami.

'He has great talents.'

This is the reason why vladet' has a very specific meaning and in no way can act as a substitute for 'have'.

\subsubsection{The logical relation of inclusion}

The only logical relation, apart from identity and non-identity, is the relation of inclusion, which presupposes two incommensurable entities, i.e., element and class (the logical varieties of what we initially called 'part' and 'whole'). Note that this relationship can be traced back to the important perceptual notions of 'figure' and 'ground' - they are incommensurable, too.

\section{$\mathbf{B} \in \mathbf{A}$}

Fig. $16 \mathrm{~B}$ is an element of the class A

The inclusion function of the instrumental can be shown by (26a) which should be compared to (26b):

(26) a. On byl pisatelem.

'He was a writer.'

b. On byl pisatel'.

'He was a (real) writer.'

In (26a) the instrumental categorizes / defines the person as a writer, i.e., he was a person who belonged to the class of writers. In (26b) the nominative case characterizes him in the capacity of being a writer.

\subsubsection{Reflexes}


We argue that the correlative viewpoint together with the relation of interrelatedness can be said to have the following reflexes in the instrumental subsystem:

Spatial reflex: Via (i.e., path).

\section{VIA \\ $\mathbf{A}>\mathbf{B}$ \\ Riding}

(27) Oni exali polem.

'They rode through the fields.'

Temporal reflex: Interval.

\section{INTERVAL}

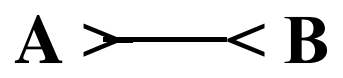

Talking

(28) Staruxi boltali časami.

'The old women talked for hours.'

Figurative reflex: Means.

\section{MEANS \\ Agent $>$ Recipient \\ Telling}

(29) Ivan pereskazal Maše tekst svoimi slovami.

'Ivan retold Maša the story in his own words.'

As appears from the figure, the role Means has a perceptual background: it defines the Patient's way from the Agent to the Recipient. That is to say, in our case the Means "his own words" bear the Patient "the text" from the Agent "Ivan" to the Recipient "Maša". In other words, The Means Role is just a metaphorical understanding of what we have named VIA.

\subsubsection{Summarizing remarks}

It should be noted that part-whole is linked solely to spatial relations in Cognitive Linguistics and it has in no way been connected to the instrumental case (Langacker 1991). We also want to note - although it seems redundant - that in linguistics the relation of inclusion is normally associated with the genitive case. Let us illustrate the various links between the different uses of the instrumental in figure 17 (for different accounts, see, e.g., Kilby 1986; Zalizniak 1996; Rakhilina \& Tribushinina 2011; Zel'dovič 2012, pp. 472-542): 


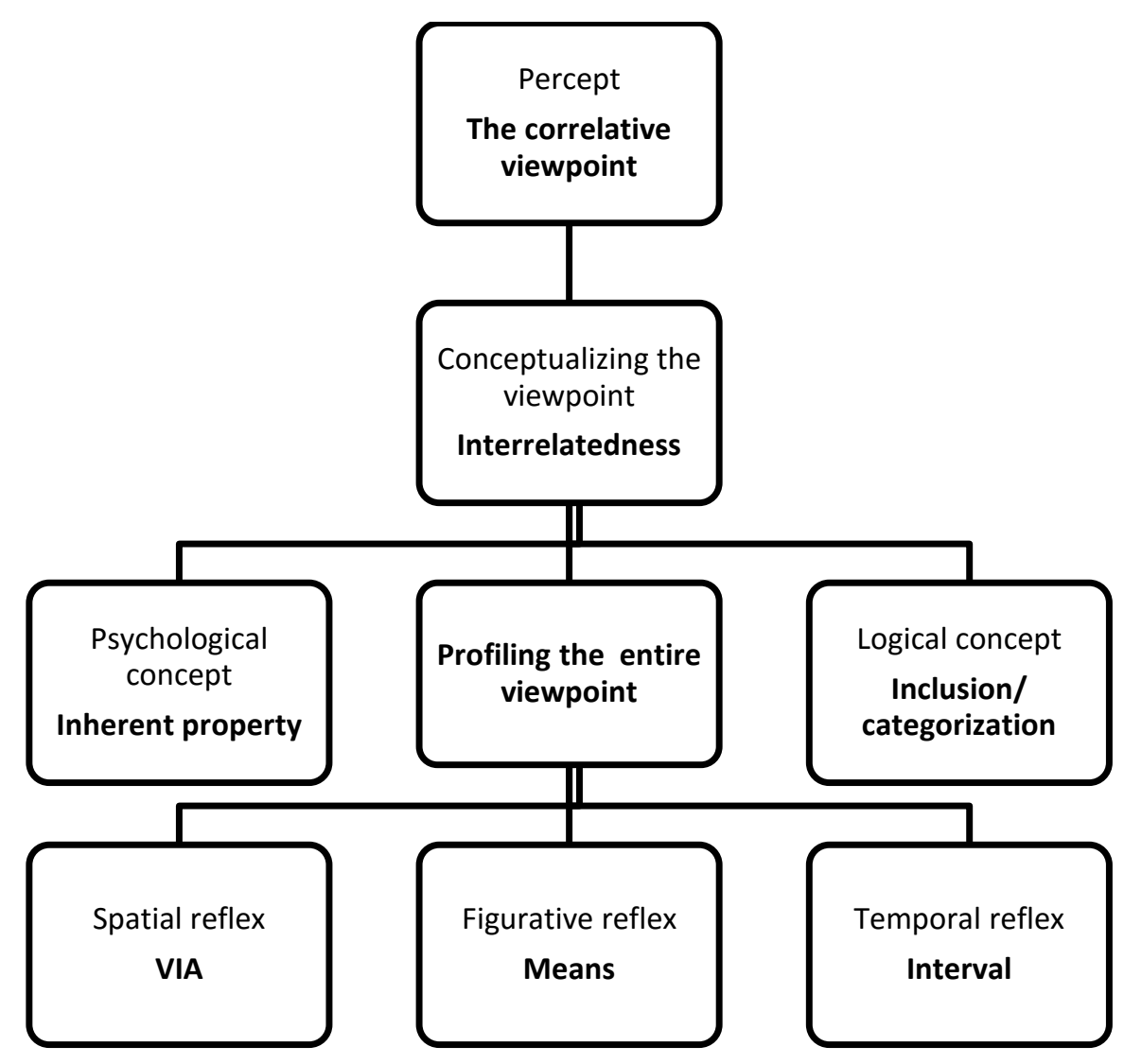

Fig. 17 The semantic hierarchy of the instrumental

\section{The semantic system of prepositional case}

\subsection{Contact vs. non-contact cases}

In the prepositional case system the nominative and the vocative fall out and the locative, which had no place in the Russian system of pure case, enters. Since the locative case takes over the nominative's place in the system of direct cases, there are no changes in the overall structure of prepositional case compared to that of pure case. The overall structure of the two systems is isomorphic and the difference between them is solely a difference of domain. It goes without saying, however, that it is impossible to apply the notion of local reference to prepositional phrases, simply because all prepositions presuppose local existence. However, the notion which is applicable to prepositional case can and should be traced back or otherwise be related to the notion of local vs. non-local reference. We shall argue that the notion of contact is the prepositional analogue to the notion of local reference, whereas no contact is analogous to nonlocal reference, cf. Durst-Andersen 2000 (The notion of contact played a dominant role in Hjelmslev's case theory and in Anderson's localistic case theory (1971)).

This means that the locative and the accusative are contact cases (corresponding to direct cases), while the genitive, the dative and the instrumental are non-contact cases (corresponding to oblique cases):

\begin{tabular}{|c|l|}
\hline CONTACT CASES & NON-CONTACT CASES \\
\hline LOCATIVE AND ACCUSATIVE & GENITIVE AND DATIVE \\
\hline
\end{tabular}




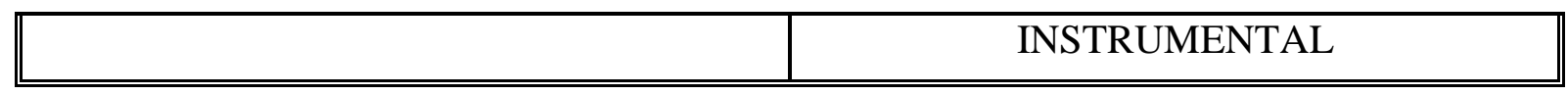

Table 3 The major classes of prepositional case

Within contact cases the accusative is dynamic, i.e., it marks a change from not being in contact to being in contact, while the locative is static, i.e., it presupposes permanent contact. Within non-contact cases the instrumental is static, whereas the two others are dynamic. The dative marks a direction from something distant to something near (rapprôchement 'approaching' in Hjelmslev's terminology), while the genitive marks a direction from something near to something distant (éloignement 'moving away' in Hjelmslev's terminology).

3.2 The accusative and the locative as contact cases

\subsubsection{The accusative vs. the locative}

The accusative and the locative cases are united by involving the notion of contact, but separated by the dynamicity vs. stativity distinction - the locative denotes permanent contact, while the accusative denotes change of contact, i.e., from being out of contact to being in contact. ${ }^{16}$ Note that all a-examples involve the locative case, whereas all b-examples involve the accusative case (cf. Plungjan 2002):

a. On sel na beregu.

'He sat down on the beach.'

b. Kosmičeskij korabl' sel na Lunu.

'The space craft has landed on the moon.'

a. Kal'man zakričal, prosnulsja i sel na krovati. ${ }^{17}$

'Kal'man cried, woke up and sat on the bed.'

b. A noč'ju on prišel ko mne, sel na krovat' i poprosil sigaretku. ${ }^{18}$

'And at night, he came to me, sat down on the bed and asked for a cigarette.'

(30a) and (31a) are used when a person is standing on a beach or lying in bed and then sits down or sits up. In those two cases there is no change of location, but a permanent contact between the agent and the beach in (30a), and between the agent and the bed in (31a). The only thing that is changed is manner of location ${ }^{19}$. Before producing the activity the person in question was in an upright or lying position, while after having performed it he is in a sitting position. (31b) is used about a spacecraft when it lands on a new location and (31b) is used when a person is standing on the floor and then sits down on a bed. In these cases we observe not only a change of manner of location, but also a change of the location itself which automatically implies change from being out of contact to being in contact with the new location. In other words, permanent contact yields the locative case, while change of contact yields the accusative case. That is the reason why "to write on the blackboard with chalk" is rendered by the locative, whereas "to knock on the door" is rendered by the accusative:

\footnotetext{
${ }^{16} \mathrm{We}$ discuss the accusative and the locative denoting time and space separately in a paper under preparation. For other accounts, see Nesset 2004; Makarova \& Nesset 2013.

${ }^{17}$ Nagibin, Jurij. (1972-1979). Blestjaščaja i gorestnaja žizn' Imre Kal'mana. Retrieved from: www.ruscorpora.ru.

${ }^{18}$ Aksenov, Vasilij. (1961). Zvezdnyj bilet. Retrieved from: www.ruscorpora.ru.

${ }^{19}$ For a detailed lexical semantic description of $n a$, though with no relation to case semantics, see Seliverstova 2000.
} 
a. Ona pišet na doske.

'She is writing on the blackboard.'

b. Ona stučit v dver'.

'She is knocking on the door.'

In (32a) it is presupposed that there is permanent contact between the chalk and the blackboard (Note that one is not writing on the blackboard when one is forced to take away one's hand in the period between ending and starting writing). In (32b) she could not be said to be knocking on the door unless she several times had moved her hand from the door, i.e., out of contact, and then moved it back, i.e., into contact with it. Let us now consider the following examples with the locative and the accusative which at first glance seem to contradict one another:

a. Segodnja, 14 dekabrja, kitajskij lunoxod vpervye sel na Lune. ${ }^{20}$

'Today, December 14, China's moon rover touched down on the Moon for the first time.'

b. My vypili, vključili radio i uslyšali, čto imenno v èti mgnovenija "Apollo" sel na Lunu. ${ }^{21}$

'We had a drink, turned on the radio and heard that exactly at that moment Apollo landed on the Moon.'

(33b) is the normal way to express that an aircraft has landed on the Moon. It is stated that it went from being out of contact into contact with the Moon. (33a) forces another reading. Here the aircraft is so close to the Moon that in one way or the other it is in contact with it although physically it is not. The point is, however, that because of the locative case (31a) only denotes the absolutely final moment when it touches ground. One might argue that the aircraft was "standing" just above the ground before it "sat" on it. Note in this connection that the locative case is also used, when the addressee knows that, for instance, a certain person has sat down, but does not know exactly where. The speaker takes into consideration the old piece of information by using the locative - only the noun of the location itself is new to the addressee.

That the notion of contact plays a crucial role in connection with the accusative case, appears very clearly from the following examples which all involve prepositions that we are used to connect with other cases than the accusative, but which in these uses simply demand the accusative. This pertains to the prepositions $p o, s$ and $o$. Let us start with po, which normally governs the dative and the locative case:

(34) a. Ona v otpuske s pervogo po devjatoe aprelja.

'She is on holiday from the first to the ninth of April.'

b. Ona v otpuske s pervogo do devjatogo aprelja.

'She is on holiday from the first to the ninth of April.'

c. Ona vošla v vodu po pojas.

'She went into water up to her waist.'

d. On zanjat po gorlo.

'He is fed up with work.'

\footnotetext{
${ }^{20}$ Retrieved from: http://in-space.info/news/kitaiskii-lunokhod-vpervye-sel-na-lune-poyavilis-podrobnosti.

${ }^{21}$ Evtušenko, Evgenij. (1999). Volčij passport. Retrieved from: www.ruscorpora.ru.
} 
In (34a) with the accusative the notion of contact comes into the picture because it states that the ninth is included. (34a) should be compared to (34b) with the genitive where it is stated that the ninth is not included - therefore she will return to her work on the ninth of April and not on the tenth of April as in the case of (34a). Both (34c) and (34d) involve the accusative. In (34c) po is used in its dynamic meaning where it is stated that she stopped going further out into the water when the water reached her waist - in (34d) it seems to be used in its static meaning, where it is stated that he is filled with work up to his throat. However, the notion of dynamicity is obviously implied here.

The same applies to the preposition $s$, which usually governs the genitive and the instrumental, but in the case of contact suddenly takes the accusative. (34a) asserts that there is contact between the female person and the speaker with respect to height. The same line of thinking is found in (34b) which should be contrasted with (34c).

a. Ona rostom s menja.

'She is (about) my size.'

b. No vot na puti vstretilas' ol'xa tolščinoj s ruku. ${ }^{22}$

'On his way he passed an alder tree thick as an arm'.

c. Vysokij, s polmetra, $\mathrm{i}$ tolščinoj v ruku, stalagmit byl prozračen i čist. ${ }^{23}$

'The stalagmite, high and arm-thick, was limpid and clear.'

As it appears, the only difference between the two constructions in (35b) and (35c) is that the $s$ construction involves a comparison - just like (35a), while the $v$-construction is used as a kind of unit of measurement.

We shall end with the preposition $o$ which normally governs the locative case as in (36a), but obligatorily takes the accusative in cases like (36b) (cf. Mel'čuk 1986, p. 83; Plungjan 2002):

a. Oni govorili o futbol'nom matče.

'They talked about the soccer match.'

b. On spotknulsja o kamen'.

'He stumbled against a stone.'

In (36a) some people are in permanent verbal contact with the topic "soccer match", whereas in (36b) a person suddenly comes into contact with a stone.

Note also the following uses of pod, lit. 'under', and $z a$, lit. 'behind', which are restricted to scalar values, i.e., temperature, mass, height, age, etc.:
a. Emu uže za pjat'desjat.
'He is already over fifty.'
b. Emu pod pjat'desjat.
'He is getting on for fifty.'

The two prepositions are here used vertically, just as a thermometer: pod means 'just below a certain limit', while $z a$ means 'on the other side of a limit', i.e., above. Although, admittedly, both examples do not explicitly involve the notion of change of contact, they both imply

\footnotetext{
${ }^{22}$ Musatov, A. I. (1957). Bol’šaja vesna. Retrieved from: www.ruscorpora.ru.

${ }^{23}$ Serafimov, Konstantin. (1994). Ékspedicija vo mrak. Retrieved from: www.ruscorpora.ru.
} 
dynamicity, as indicated by the translations. The two prepositions also occur in other meanings (still with the notion of dynamicity implied):

a. On rabotaet za menja.

'He works instead of me.'

b. On rabotaet na menja.

'He works for me.'

(39) a. Neizvestnyj imitator pel pod Šaljapina.

'An unknown imitator sang a la Šaljapin.'

b. Ėta korzina u menja pod musor.

'I use this basket for garbage.'

In (38a) za means 'as a substitute' for another person who normally occupies the position. This is opposed to (38b) which means that the person is an employee with another person - in other words, in this case he is earning money for that person. Both (39a) and (39b) exemplify a special meaning of pod that can be said to be close to the meaning of the prefix pod-in connection with motion verbs, viz. dynamicity and closeness. In (39a) the person in question produces singingactivity under the "active" influence of Šaljapin, i.e., when singing one simulates the characteristic resonance and vibrancy of Šaljapin's voice. (39b) should also be read in a literal way: when one has some garbage and wants to get rid of it, then the basket should be under it. As we see, in both cases pod retains its meaning, and the accusative implies the notion of change of contact, i.e., a change from not being in contact to being in contact. (For a detailed semanticsyntactic description of constructions with pod, see Kuznetsova, Plungian \& Rakhilina 2013; Raxilina \& Plungjan 2014). For all other uses, see 3.3.3.

3.3 The genitive, the dative, and the instrumental as non-contact cases

\subsubsection{The genitive}

The genitive is a non-contact case with the extrovertive viewpoint, i.e., it denotes a relation or a direction that goes from something near, A, to something distant, B:

\section{(X) $\mathbf{x}\} \mathbf{A} \rightleftharpoons \mathbf{B}$}

Fig. 18 The extrovertive viewpoint

The extrovertive viewpoint is verbalized by a couple of double prepositional phrases:

(40) a. S desjati do dvux.

'From 10 am to 2 pm.'

b. Ot Puškina do našix dnej.

'From Pusjkin to our time.'

c. Ot Moskvy do Berlina.

'From Moscow to Berlin.' 
When the entire viewpoint is verbalized, i.e., from the starting point, A, to the terminal point, B, the preposition $s$ is only used in connection with time, as in (40a). In all other cases one has to use ot - this means that it has to be used in connection with animate nouns as in (40b) and in connection with inanimate nouns as in (40c). The preposition $i z$ cannot be combined with $d o$, only with $v$ (which takes the accusative and establishes contact) whereby the extrovertive viewpoint, from A until/to B, cannot be said to be verbalized.

Used dynamically with a verb naming an activity or an action, the genitive denotes a direction which proceeds from a place where somebody (cf. 40a and 40b) or something (cf. 40c) is in contact to a new place whereby he or it loses contact with the first place:
a. Studenty vyšli iz auditorii.
'The students went out of the class.'
b. Otec vernulsja s raboty.
'My father returned from work.'
c. Aspirant polučil pis'mo ot svoego naučnogo rukovoditelja.
'The Ph.D. student has received a letter from his supervisor.'

In these cases $i z$ is used when we are dealing with the interior part of an object (cf. 40a), but $s$ when dealing with the exterior part of an object or a place understood as a place of work (cf. $41 \mathrm{~b}$ ). This means that $s$ and $i z$, on the one hand, and $n a$ and $s$, on the other, are converse: nouns that take $v$ will also take $i z$, while nouns that take $n a$ will also take $s$. The preposition $o t$ is in this function restricted to human beings (cf. 41c) $)^{24}$.

Just as the extrovertive viewpoint could explain why verbs such as dostignut' / dostigat' 'reach', on the one hand, and verbs such as izbežat' / izbegat' 'avoid', on the other, govern the genitive, it can also be used to explain why prepositions like dlja 'for' and radi 'for one's sake', on the one hand, and prepositions like mimo 'past', on the other, do not govern the dative or the instrumental, but the genitive:
a. On pišet stixi dlja detej.
'He writes poems for children.'
b. On sdelal vse èto radi ženy.
'He did it all for his wife's sake.'
c. Oni edut mimo universiteta.
'They are driving past the university.'

(42a) and (42b) deal with the notion of objective or purpose which is linked to the extrovertive viewpoint itself: what the writer or husband is doing is going from them, i.e., from what is near, to, respectively, children and wife, i.e., to what is distant (cf. lexical semantic description of these prepositions in Apresjan 1995). In (42c) the persons avoid the university - they do not get into contact with it.

The following prepositions govern the genitive because they all, one way or the other, denote separation or exclusion:

\footnotetext{
${ }^{24}$ In the description of the preposition $s$ compared to iz and ot Agafonova (2000) exploits the notions of 'source' (Rus. istočnik, Fr. origine), 'viewpoint' (Rus. točka zrenija) and two 'location points' (Rus. lokalizacii), which might in some way remind of our approach, but they are used in the framework of lexical semantics and with no relation to case semantics.
} 
(43) a. Vse prišli krome prepodavatelja.

'All came apart from our teacher.'

b. Oni skučajut bez staršego brata.

'They are bored when their eldest brother is missing (lit. without) (=They are missing their eldest brother).'

c. Ona pošla vmesto menja.

'She went instead of me.'

d. On prošel vne očeredi.

'He got in out of turn.'

e. Oni sideli vokrug stola.

'They were sitting around the table.'

In (43a) the teacher has been separated from all the others and that is why he did not show up, in (43b) the sisters and brothers are bored when their eldest brother is separated from them (in other words, when he is absent), in (43c) the person referred to was either separated or avoided at the expense of another person, in (43d) the person in question avoids standing in line, and in (43e) some persons are sitting separated from a certain table, i.e., in what was called near distance. Exactly this notion is at stake in the following examples:

(44) a. Tolja živet blizko ot nas.

'Tolja lives near to us.'

b. Oni sideli u kamina.

'They were sitting by the fire.'

c. On sel vozle nee.

'He sat down near her.'

d. Domik stoit okolo cerkvi.

'The little house is near the church.'

e. Učitel' stoit u doski.

'The teacher is standing at the blackboard.'

In all five examples we are talking about separation between two entities, but at the same time about nearness - this is exactly what we call near distance. One might say that all the abovementioned prepositions have a lexical meaning that involves nearness, but a grammatical meaning that expresses distance by virtue of the extrovertive viewpoint linked to the genitive. In (44b), for instance, the persons referred to are separated from the fire, although they are sitting quite near to it, i.e., they are not in contact with the fire. In (44e), for instance, there is no contact between the teacher and the blackboard (for a different account of $u+$ genitive, see, e.g., Cienki 1995; Seliverstova 1997). We shall return to this issue in 3.3.2. and in 3.3.3.

The prepositions $i z, s$, and ot are also used figuratively (cf. 2.5.5) - in this use they all lose their (overt) dynamicity:

a. Muž ubil ženu iz revnosti.

'The husband killed his wife out of jealousy.' 
b. Ja sgorala so styda za svoj postupok.

'I burned with shame for what I had done.'

c. Ego sestra umerla ot raka.

'His sister died of cancer.'

Because different expressions tend to have different content, the three prepositions might have different meanings. This seems to be the case. (45a) with $i z$ denotes the motive of the action, i.e., what drove the husband to do the terrible thing he did in the example. Due to that $i z$ is normally used in connection with verbs denoting an agent-controlled activity. (45b) with $s$ denotes the mental state of the person before she blushed: The woman felt shame and from this feeling she got into a state of blushing. We are here concerned with a non-agent-controllable activity. (45c) with ot is used to denote the cause of death - it is the doctor's diagnosis. If a verb denotes a non-agent-controllable activity, such as, for instance, zaplakat' 'start crying', zadrožat' 'start trembling', pokrasnet' 'blush', etc., it can in principle combine with both $s$ and ot:

(46) a. Ona zaplakal s radosti / ot radosti.

'She wept with / for joy.'

b. On prosnulsja so straxu / ot straxa.

'He woke up from fear.'

c. Ona byla gotova umeret' so styda / ot styda.

'She was about to die from shame.'

d. On ogovoril sebja so straxu / iz straxa.

'He slandered himself out of fear.'

Although both variants in (46a-d) are grammatical and acceptable, they express distinct meanings. All variants with $s$ denote the mental state which obtained before the very activity started, whereas all variants with ot refer to the stretch of time when the activity itself was taking place. In other words, $s$ points to the entailment structure, while ot points to the activity description itself. This may also explain why the former naturally combines with perfective procedural verbs (e.g., Ona zaplakala $s$ radosti), whereas the latter naturally combines with imperfective activity verbs (e.g., Ona plačet ot radosti). If we compare (46b) with (46d), the difference between these two prepositions and $i z$ should be obvious: (46d) with $i z$ talks about a person who was afraid and used this as his motivation to tell a lie instead of the truth. The three prepositions do not only combine with verbs, but also with adjectives as in the following examples:

(47) a. Dobryj iz žalosti.

'Good out of pity.'

b. Bol'noj s gorja.

'Sick with grief.'

c. Potnyj ot žary.

'Sweaty because of the heat.' 
In (47a) the person feels pity and therefore he deliberately acts as a good man. In (47b) we are dealing with a person who feels grief and because of that mental state he is sick - a state that is uncontrollable in opposition to the state of being good or bad. (47c) says that some person is sweaty and that the sweat itself is caused by heat.

From the presented examples involving ot it appears that Cause is only one meaning out of several possible meanings. As a matter of fact, it can have all the meanings that correspond to the various reflexes given in 2.5.5. It can be used as Source, e.g., ključ ot dverj 'the key to the door' or pis'mo ot pervogo maja 'the letter of the first of May', as Cause, e.g., On umer ot raka 'He died of cancer', and it can be used to express what was called the Distanced Role, e.g., zaščita ot vragov 'defence against enemies'. It should be pointed out that it seems as if Russian applies another perspective than, for instance, English. English can be said to view everything from the progressive viewpoint, i.e., things are viewed prospectively: a key to a door (you have a key and it suits a certain door) and a defence against enemies (you are doing something and this something is directed against somebody else). Contrary to this, Russian can be said to view everything from the regressive viewpoint, i.e., things are viewed retrospectively (from the point of view of the origin of the item referred to or the activity implied): a key (which stems) from (i.e., ot) a door, a letter (which stems) from (i.e., ot) the first of May, the death (which stems) from (i.e., ot) cancer, and a defence (against something that stems) from (i.e., ot) enemies. If this is true Source must be the principal role from which one can derive all the other roles, including Cause - which thus is regarded as a purely contextual meaning.

The compound preposition $i z-z a$ has, however, the meaning of Cause as its only meaning when it is used metaphorically:

Vse opozdali iz-za doždja.

'All were delayed because of the rain.'

In (74) $i z-z a$, lit. 'from-behind', is used quite concretely:

Oni vstali iz-za stola.

'They rose from the table.'

The concrete use of the compound preposition exposes its double indexical value: the second part, i.e., $z a$, verbalizes the initial state of the action (Oni sideli za stolom 'They were sitting at the table'), while the first part, i.e., $i z$ (which is the governing part), verbalizes the direction of the action - they removed themselves from the table. The same applies to the other compound preposition in Russian, viz. iz-pod, lit. 'from-below':

Iz-pod zemli pojavilsja cvetok.

'A small flower appeared out of the soil.'

As in the previous example, the second part of the compound preposition, i.e., pod, verbalizes the initial state of the event, viz. the flower was under the ground, whereas the first part, i.e., $i z$, verbalizes the direction of the activity itself, i.e., the flower separated itself from this position and went out into the open air (cf. Kuznetsova, Plungian \& Rakhilina 2013).

The same stative function is also characteristic of the preposition $u$ 'with, by' when it governs an animate entity:

(51) a. Mama kupila dom u djadi.

'Our mother bought the house from our uncle.'

b. Papa zakazal kostjum u portnogo. 
'Our father ordered a suit from the tailor.'

c. U brata ukrali časy.

'A watch was stolen from my brother.'

Russian uses the stative preposition $u$ in order to point to the initial state of the action expressed by the verb. This means, for instance, that dom $u$ djadi should be read as it stands, viz. that the uncle had the house (i.e., the house existed with the uncle) before it was bought by the mother. Note that English here verbalizes the direction of the item denoted by the subject or the direct object. In other words, English uses a dynamic preposition instead of the Russian static one. Once again we realize an important difference between Russian and English.

\subsubsection{The dative}

The dative is a non-contact case with an introvertive viewpoint, i.e., it denotes a relation or a direction that goes from something distant, B, to something near, A:

\section{(X) $\mathbf{A} \longrightarrow$ B $\{\mathbf{x}$}

Fig. 19 The introvertive viewpoint

Unlike the genitive that can verbalize the entire viewpoint by means of double prepositions which both govern the genitive, the dative itself can only verbalize either the terminal point (i.e., A) or the starting point of the introvertive perspective (i.e., B). The preposition $k$ verbalizes its terminal point:
a. Ona sela k stolu.
'She sat down at the table.'
b. On pribegnul $\mathrm{k}$ ee pomošči.
'He turned to her for help.'
c. Ona privjazalas' k učitelju.
'She attached herself to her teacher.'

In (52a) we find the introvertive viewpoint manifested as a direction, i.e., somebody approached something. Because the verb is perfective, it is asserted that she is sitting near the table without being in contact with it and without being related to it in any way. Since (52b) involves an inanimate entity, while (52c) involves an animate one, the former can be said to denote a Goal, while the latter can be said to denote a Recipient. That the dative indeed is a non-contact case as Jakobson also stated, although in other terms (he used the notion of non-limit) - should appear from (53a) when it is compared to (53b):

\footnotetext{
a. K desjati emu nado ujti.

'He must be out by ten o'clock.'

b. V desjat' emu nado ujti.

'He must leave at ten o'clock.'
} 
As indicated in the corresponding translations, (53a) does not involve contact - the person in question must be out before ten o'clock, while (53b) does involve it - he must be out when the clock strikes ten. The same distinctions are present in the following two time expressions:

a. Oni vernulis' $\mathrm{k}$ večeru.

'They returned towards evening.'

b. Oni vernulis' pod večer.

'They had returned by the evening.'

In (54a) with the dative we are approaching the evening, but are not in direct contact with it, while in (54b) with the accusative we have reached the evening and are in contact with it. That the dative as well as the genitive are opposed to the accusative and the locative does also appear from the fact that it is possible to attach gradation adverbs to prepositions which govern the dative and the genitive, but not to prepositions governing the accusative and the locative. In the latter case the question is whether there is contact or not, but in the former case where we are dealing with the notion of non-contact one can be more or less close to something (see 55a) or more or less far from something (see $55 \mathrm{~b}$ ):
a. On podošel k nej sovsem blizko.
'He walked quite close to her.'
b. Ona sidela sovsem blizko ot ognja (*i grelas').
'She sat quite near to the fire (*and warmed herself).'
c. Ona sidela sovsem blizko k ognju i grelas'.
'She sat quite close to the fire and warmed herself.'

In other words, although both the dative and the genitive involve non-contact, the dative in the form of $\kappa$ signals that the person is close to something or somebody else (jf. 55a and 55c), whereas the genitive in the form of $o t$ signals that the person is separated from something else. This is also confirmed by the grammatical status of (56a) with the dative and the ungrammatical status of (56b) with the genitive:
a. On stojal blizko k dekabristskim krugam.
'He was close to the Decembrist circles.'
b. *On stojal blizko ot dekabristskix krugov.
'He was near to the Decembrist circles.'

Note that blizko $k$ with the dative resembles Eng. close to in that they both have a psychological and physical reading, whereas blizko ot with the genitive resembles Eng. near to in that they both have only the physical reading and both presuppose distance between the two entities in question.

In connection with ot the preposition $k$ can be said to verbalize the entire introvertive viewpoint - here with a temporal meaning:

(57) On ot matča k matču igraet vse lučše.

'He plays better and better from game to game.' 
The genitive prepositional phrase ot matča denotes what is more distant in time, whereas the dative prepositional phrase $k$ matču denotes what is closer in time. What is close and cannot be separated is included in the following expressions:
a. Pečen'e k čaju.
'Pastry for tea.'
b. Xleb k obedu.
'Bread for the dinner.'
c. Uvertjura k "Pikovoj dame".
'The overture to "Queen of Spades".'

The prepositions vopreki 'despite, against', naperekor 'against' and napererez 'across' verbalize the starting point of the introvertive viewpoint - they thus resemble all verbs that mean "meeting smb. or smth." and which all govern the dative:

(59) a. Pacient dejstvoval vopreki zdravomu smyslu.

'The patient acted against common sense.'

b. Deti inogda postupajut naperekor vzroslym.

'Sometimes children act contrary to the adults' opinion (disregard adults).'

c. Demonstranty brosilis' napererez tankam.

'The demonstrators rushed to intercept the tanks.'

The preposition po denotes what was called the Model or Recipe Role (for a different account, see, e.g., Bethin 1983):

(60) a. Oni exali po šossejnoj doroge.

'They were going by the main road.'

b. Afrika - vtoroj po veličine kontinent.

'Africa is the second largest continent.'

c. Soldaty otkryli ogon' po vragu.

'The soldiers opened fire against the enemy.'

All have underlying "to follow smth. or smb.". For instance, (60b) can be said to have the paraphrase: If one follows the size of continents, Africa is the second largest. Compare the following two examples:

(61) a. Po moim časam sejčas sem' časov.

'By my watch it is now seven o'clock.'

b. Na moix časax sejčas sem' časov.

'On my watch it is now seven o'clock.'

While (61a) explicitly states that if you follow my watch, i.e., use my watch as a model, then it is seven o'clock. (61b) only implies this - it points to the watch as a location point. 
The preposition po is also used to denote repetition, i.e., identity in time or the result of having followed the same model every time:
a. Oni prixodjat k nam po subbotam.
'They come to us on Saturdays.'
b. Oni zanimajutsja po večeram.
'They study every evening.'
c. Oni zanimajutsja každyj večer.
'They are studying every evening.'

Note that the po-construction with the dative always involves a characterization (cf. the English translation with the simple present tense). In order to give a situation description one has to use a construction with každyj 'every' in the accusative (cf. 62c). Once again we realize the important distinction between local vs. non-local reference established by the direct vs. oblique case distinction.

The preposition podobno 'like' also denotes identity or the same model:

(63) Oni dejstvujut podobno svoim predšestvennikam.

'They act like their predecessors.'

In that way the prepositions governing the dative not only reflect the introvertive viewpoint in its two varieties, but also the various reflexes of the concepts derived from this viewpoint.

\subsubsection{The instrumental}

Like the genitive and the dative, the instrumental is a non-contact case, but unlike the two other cases, which are relative cases, the instrumental is a correlative case. This means that all the prepositions governing the instrumental cannot but denote an interrelationship between something near and something distant (see the following figure, which includes all the prepositions governing the instrumental apart from $c$ 'with').

nad 'above'

\section{[A]}

pered 'before' $[\mathrm{A}] \quad$ meždu 'between' [B] za 'behind'

[B]

pod 'under'

Fig. 20 All possible kinds of interrelationship

In an example like (64) one could of course get the idea that there was/is contact between the snake, that is near, and the stone, that is distant. It should, however, be stressed that although the two entities are interrelated to one another we are not concerned with contact between them - we 
could not be, because we cannot be looking at the correlation between something near and something distant without implying a certain distance, i.e., non-contact ${ }^{25}$ :

(64) Zmeja ležit pod kamnem.

'The snake is (lit. lying) under the stone.'

If one feels that the concept of contact is involved, it is because of our background knowledge according to which stones cannot float. As a matter of fact, if there were contact, the snake would have been dead.

In connection with the preposition $s$ '(together) with' the notions of being near and being distant are quite obvious:

(65) Ona pošla s rebenkom v polikliniku.

'She went to the clinic with her child.'

In (65) the nominative marks that the mother is near, i.e., she is more central and foregrounded, and the instrumental marks that the child is distant, i.e., it is more peripheral and backgrounded. At the same time, the instrumental asserts that the mother and the child are interrelated. The choice between the nominative and the instrumental is thus dictated by the notions of foregrounding and backgrounding and has nothing to do with who is in charge, as appears from the following example:

(66) Sestra zanimaetsja so mnoj každyj den'.

'My sister is studying with me every day / I am studying with my sister every day / My sister and I are studying together every day.'

(66) may refer to three different situations as it appears from the English translations given above. What is important in all three kinds of situations is that the two persons are interrelated. The importance of this notion should appear from the following two examples where the instrumental is compared to the genitive:
a. On živet rjadom s nami.
'He lives next to us.'
b. On živet poblizosti ot nas.
'He lives near to us.'

In $(67 a)$ with the instrumental we feel a certain correlation between the person in question and us: We may be friends, neighbours, or otherwise related, whereas there is no correlation whatsoever in (67b). As a matter of fact, we here feel a certain distance. The same applies to the following examples:

(68) a. Ona sidela rjadom so mnoj i plakala.

'She sat next to me and cried.'

b. Ona sidela blizko ot menja i plakala.

'She sat near to me and cried.'

c. Ona stojala za mnoj.

\footnotetext{
${ }^{25}$ In Plungjan \& Raxilina 2000 it is mentioned that pod can denote both contact and non-contact as well as both stativity and dynamicity, but these meanings and functions are not related to case semantics.
} 


\section{'She stood behind me.' \\ d. Ona stojala szadi menja. \\ 'She stood behind me.'}

In (68b) with the genitive there is no relation at all between the woman and me, while this is the case in (93a) with the instrumental. The same is true of (68c) and (68d). The latter example with the genitive lacks the idea of close proximity that adheres to the former with the instrumental. Here it is explicitly stated that they have something in common.

It is important to emphasize that the instrumental has only a static meaning:
a. Ona vežliva so vsemi.
'She is polite with everyone.'
b. Ona vežliva ko vsem.
'She is polite towards everyone.'

(69a) states that when she is together with people she is always polite, while (69b) says that she treats people in a polite way. In the former case you are referring to an experience of her as a person (it is static); in the latter case you are referring to an experience of her behaviour (it is dynamic). All dynamic readings where the notion of contact comes into the picture are taken care of by the accusative:

(70) a. Vse sideli za stolom.

'They were all having dinner (lit. sitting behind the table).'

b. Vse seli za stol.

'They sat down to have dinner (lit. sat down behind the table).'

(71) a. Oni živut pod Moskvoj.

'They live in the outskirts of Moscow.'

b. Oni pereexali pod Moskvu.

'They moved to the outskirts of Moscow.'

In both a-examples we observe a static reading, where there is a certain correlation between the subject and the governed noun (which is absent in the English translations). In (70a) they are not just sitting at the table, they are having dinner - so what they are doing is related to where they are sitting. In (71a) they live in the neighbourhood of Moscow. In all b-examples the notion of contact comes into the picture, and the accusative takes over.

It is important to note that the notion of contact which might be expected in the case of pered 'in front of' and nad 'above' does not make sense:

(72) a. Oni stojali pered vxodom.

'They were standing in the front of the entrance.'

b. Oni ostanovilis' pered vxodom.

'They stopped before the entrance.'

(73) a. Lampa visit nad stolom.

'The lamp hangs above the table.' 
b. Oni povesili lampu nad stolom.
'They put up a lamp above the table.'

Although the b-examples all denote motion and imply a certain direction, they do not accept the accusative as it appears from the examples. The reason must be that although we are concerned with psychological contact - in (72b) we are presumably talking about an entrance that we want to use and in (73b) we are talking about a lamp which will be used when dining - there is no way to apply the notion of physical contact, which seems to presuppose the notion of penetration of sphere of influence - otherwise it will be impossible to explain why pered 'in front of' and nad 'above' cannot take the accusative, whereas za 'behind' and pod 'below' can (cf. Pajar \& Plungjan 2000 where the notion of 'lack of contact' is used, but it is applied to the description of the core meaning of nad itself).

It should be noted that in those cases where $z a$ takes the instrumental although the verb is dynamic, we are in fact not dealing with contact:

a. Ona smotrit za det'mi.
'She is looking after the children.'

b. On sledit za rezul'tatami.

'He follows the results.'

c. Ona xodit za pokupkami po utram.

'She goes shopping in the morning.'

All the verbs in (74) give the idea that a certain person is behind something and from that position s/he is producing the activity denoted by the verb. For instance, in (74a) the female person is behind the children and from this position she is following them with her eyes.

The preposition meždu 'between' is unproblematic, but it should be mentioned that in some idiomatic expressions (which all presuppose dynamicity) it does not take the instrumental, but the genitive: měz(du) dvux stul'ev '(caught) between two stools', měz(du) dvux ognej '(caught) between two fires', and mě̌z(du) strok '(read) between the lines'.

\subsection{On the notion of contact vs. non-contact in connection with direct and oblique objects}

At this particular place it seems appropriate to mention that the notion of contact vs. non-contact within the prepositional case system seems to have had a retroactive influence on the pure case system. The idea itself was evoked by simultaneously considering two sets of unrelated facts. First, how can we explain that verbs in Old Russian (OR) that meant 'to see / watch / look at' all governed the genitive, but in Modern Russian (MR) govern the accusative? In our terminology this is tantamount to saying that in OR these verbs were identified with the extrovertive viewpoint of the genitive, but are not anymore in MR. Now they seem to be identified with visual contact to the physical object and through that with local reference. Secondly, why do many oblique objects in Russian correspond to transitive objects in other languages? In other languages, verbs for 'to fear', 'to desire', 'to abuse', 'to cheat', 'to sacrifice' govern the accusative case and seem to be in no need for an oblique case marking. What is at stake?

A possible common explanation is that in MR the notion of contact from the prepositional case system has been coupled directly to accusative objects, i.e., direct objects of transitive verbs, whereas the notion of non-contact has been coupled to genitive, dative and instrumental objects, i.e., oblique objects of intransitive verbs. In short, the prepositional concept pair 'contact vs. non-contact' has been linked to the verbal concept pair 'transitivity vs. intransitivity'. This is 
quite natural, since prepositions as well as verbs involve the notion of government. We thus suggest that two semantic notions have been transferred from one place to another place by means of their identical syntactic function. The result of this transfer is the creation of two macro-roles (see below).

As already mentioned, the genitive, dative and instrumental cases function as a broad subjunctive mood: they treat the lack of equality as a matter of fact, i.e., the person or thing named by one of these three oblique cases is not present in the de facto situation referred to by the verb. The "modal" difference between them seems to correspond to the distinction between 'objective mood' (genitive) and 'subjective mood' (dative and instrumental) - a mood distinction which is found in several Native American languages (cf. Whorf 1950). In Hopi this mood distinction is found between what Whorf called 'manifested in the world', i.e., it refers to something that had or has a real existence and therefore will be able to have a future existence, and what he calls 'manifesting in the world', i.e., it refers to something that comes into existence only through language, e.g., cause-effect, purpose, simultaneity, etc. which are all non-palpable entities (cf. dependent modes, Whorf 1936).

Let us apply this way of thinking to Russian. If " $\mathrm{X}$ wishes $\mathrm{Y}$ " (želat' čego-l.) or if "X fears $\mathrm{Y}$ " (bojat'sja čego-l.), then $\mathrm{Y}$ will be in the genitive case, because "Y" is not present in the situation, where "X" is having a wish for " $Y$ " or is feeling a fear of "Y". In the former case genitive is used as a kind of 'desiderative' (the static variant), and in the latter case as a kind of 'obviative' (the dynamic variant). We are dealing here with objective (external) reality, which can be touched, seen or heard: If you wish for cold weather, there is no cold weather (static use); if you fear snakes, you in fact avoid them, try to stay out of contact with them (dynamic use).

The dative and the instrumental do not deal with objective (external) reality, but with what could be called subjective (internal) reality. If "X is unfaithful to Y" (izmenjat' komu-l.) or if "X maltreats Y" (pomykat' kem-l.), there is no local reference in either instance: in the former instance " $\mathrm{X}$ " is doing something with somebody else, but not with "Y"; in the latter instance "X" is not doing something directly to " $Y$ " - there is no contact between " $X$ " and "Y". Therefore the accusative case is out of the question. Although they are not a direct part of the situation named by their respective verbs, they are both part of another situation which belongs to internal reality. In the case of " $\mathrm{X}$ is unfaithful to $\mathrm{Y}$ ", $\mathrm{Y}$ is put in the dative case because " $\mathrm{Y}$ " is affected indirectly by "X' $\mathrm{s}$ " behaviour or because "Y's" mental state is altered by it ("Y" bears what could be called the Male-/Benefactive Role). In the case of " $X$ maltreats $Y$ ", $Y$ is put in the instrumental case because "Y" is used as a means - not directly, but indirectly ("Y" carries the so-called Victim Role - the animate counterpart to Means). All these roles seem to be indirect varieties of what is normally called Patient, i.e., there is no direct, but only an indirect contact between the Agent and the Patient. Since this seems to be a general phenomenon, the conclusion must be that the prepositional case system has had an influence on the pure case system. There is no other way to explain this.

In connection with transitive action verbs all direct objects carry what we call a Direct Patient Role, i.e., there is a direct contact between the Agent and the Patient. That is why the verbs in OR that governed the genitive (cf. above) now govern the accusative. One might say that the notion of contact, in this case visual contact, exceeded the notion of viewpoint. In that way, the modal existence of the object became absolute and $X$, the subject of the verb, got into contact with Y, its object, by means of the verb itself instead of just marking a certain direction. In short, these verbs went from being intransitive in OR to transitive in MR. In connection with intransitive verbs governing an oblique (genitive, dative, or instrumental) case all oblique objects carry what we call an Indirect Patient Role - they are suffering from the activity, but there is no contact between the Agent and the Patient. It is essential to point out that the roles of Direct Patient and Indirect Patient are instantiations of the major division between direct and oblique cases of the pure case system. Therefore they can be argued to be genuine case roles, i.e., two macro-roles which are specified depending on morphological case (for instance, as the Distanced 
Role if it is a genitive object, as the Victim Role if it is an instrumental object, or as the Male/Benefactive Role if it is a dative object). The interesting thing, however, is that the two instantiations seem to be caused by a phenomenon from outside, viz. the notion of contact vs. non-contact from the prepositional case system.

\section{Concluding remarks}

We have just described Russian case in purely semantic terms without any reference to syntactic functions. This was enabled by viewing the pure case system as the nominal equivalent to mood. It was demonstrated that not only are the nominal and verbal systems in Russian hierarchically built up, but also its mood and case system. Just as Russian mood presupposes the existence of the categories of aspect and tense, Russian case presupposes the existence of the categories of animacy / inanimacy and number. This also appears clearly from the ordering of the various morphemes. By presupposing two other categories case, as well as mood, can be said to be a relational category that establish a relationship between the output of the two other categories, be they verbal or nominal. With respect to case, we sharply distinguish between the mini case system (the central system) and the pure oblique case system (the peripheral system). The genitive is part of both systems. As direct cases in the mini system the nominative and the accusative resemble the indicative mood by asserting local reference, i.e., the person or thing denoted by the nominative and the accusative are indeed present in the situation referred to. As oblique cases in the mini system the vocative and the genitive function as non-indicative forms. The vocative resembles the imperative mood by demanding local reference, whereas the genitive resembles the subjunctive mood by asserting non-local reference, i.e., the person or thing denoted by the genitive noun is not present in the situation referred to.

When the genitive is not opposed to the nominative or the accusative, it enters into the pure oblique case system. Here the person or thing denoted by the genitive, the dative or the instrumental are not viewed from the point of view of absolute existence, but from the point of view of modal existence. It turned out that the genitive is coupled to an extrovertive viewpoint, the dative to an introvertive one and the instrumental to a correlative viewpoint. These are the three possible viewpoints. It is not possible to find a fourth one, because they enter into a specific hierarchy. The genitive viewpoint is the first and natural viewpoint - children are born with that viewpoint. The dative viewpoint presupposes the genitive one and is converse to it. The instrumental viewpoint presupposes both the genitive and the dative, but also incorporates them by simultaneously applying both viewpoints, however, from an external point of view. This explains in a natural way why languages may have the genitive without the dative and the instrumental (Danish), why languages may have the genitive as well as the dative but not the instrumental (German) and why languages having the instrumental also have the genitive and the dative (Russian).

We also attempted to demonstrate that the structure of the prepositional case system in Russian is isomorphic to its pure case system which is considered to be the basic one. In the prepositional case system the locative enters into the place of the nominative, while the accusative retains its position. The notion of local reference from the pure case system is replaced by the notion of contact - all prepositions demand local reference so we should not expect the prepositional cases to act exactly as the pure cases. This means that the accusative and the locative both involve contact. The difference between them is that the locative denotes permanent contact, whereas the accusative denotes change of contact. The three oblique cases of the prepositional case system behave as they do in the pure case system.

Because the notion of local reference goes back to the perceptual notion of figure-ground and because the three viewpoints represent three different percepts, our case-as-mood theory can be said to be grounded on visual perception - not on cognition. One might expect that such a view on Russian case would yield broad and inaccurate descriptions of concrete uses of case in 
Russian, but, as demonstrated throughout the paper, this is obviously not the case. The precise and unambiguous descriptions were achieved by deriving various concepts from the three percepts and by creating various reflexes when these concepts meet other broader concepts.

\section{References}

Agafonova, K. (2000). O konstrukcii "predlog $s+$ genitive". (Perevod s francuzskogo V. A. Plungjana). In D. Pajar \& O. N. Seliverstova (Eds.), Issledovanija po semantike predlogov. Sbornik statej (pp. 313-337). Moskva.

Andersen, H. (2012). The new Russian vocative: synchrony, diachrony, typology. ScandoSlavica, 58(1), 122-167.

Anderson, J. M. (1971). The grammar of case: towards a localistic theory. Cambridge.

Apresjan, V. Ju. (1995). Dlja i radi: sxodstva i različija. Voprosy jazykoznanija, 3, 17-27.

Babby, L. H. (1980). Existential sentences and negation in Russian. Ann Arbor.

Babby, L. H. (2002 [1989]). Subjectlessness, external subcategorization and the projection principle. Zbornik Matice srpske za filologiju i lingvistiku, 32(2), 7-40. [Reprinted Journal of Slavic Linguistics, 10, 341-88.]

Belošapkova, V. A. et al. (Eds.) [1981] 1997. Sovremennyj russkij jazyk. 3-e izd., ispr. i dop. Moskva.

Bethin, Ch. Y. (1983). The meaning of po + dative case in spatial sentences. Russian Language Journal, 37(128), 27-34.

Beytenbrat, A. (2015). Case in Russian. A sign-oriented approach. Studies in Functional and Structural Linguistics (SFSL). Amsterdam / Philadelphia.

Bilý, M. (1990). The case remains open. Some notes on a new book on morphological case in Russian. Russian linguistics, 14, 185-203.

Borschev, V., Partee, B. H. (1999). Semantika genitivnoj konstrukcii: raznye podxody k formalizacii. In E. V. Rakhilina \& Y. G. Testelets (Eds.), Tipologija i teorija jazyka: Ot opisanija $k$ ob'jasneniju. K 60-letiju Aleksandra Evgen'eviča Kibrika (pp. 159-172). Moscow.

Cejtlin, S. N. (2000). Lingvistika detskoj reči: Učebnoe posobie dlja studentov vysšix učebnyx zavedenij. Moskva.

Cienki, A. (1993). Experiencers, possessors, and overlap between Russian dative and u + genitive. In J. S. Guenter, B. A. Kaiser \& Ch. C. Zoll (Eds.), Proceedings of the nineteenth annual meeting of the Berkeley Linguistics Society: General session and parasession on semantic typology and semantic universals (pp. 76-89), Berkeley.

Cienki, A. (1995). The semantics of possessive and spatial constructions in Russian and Bulgarian: a comparative analysis in Cognitive Grammar. Slavic and East European Journal, 39, 73-114. 
Comrie, B. On delimiting cases. In R. D. Brecht \& J. S. Levine (Eds.), Case in Slavic (pp. 86106). Columbus, Ohio.

Corbett, G. G. (2008). Determining morphosyntactic feature values: the case of case. In G. G. Corbett \& M. Noonan (Eds.), Case and Grammatical Relations. Studies in honor of Bernard Comrie (Typological Studies in Language 81) (pp. 1-34). Amsterdam / Philadelphia.

Daniël', M. A. (2008). Zvatel'nost' kak diskursivnaja kategorija. Neskol'ko gipotez. In V. A. Plungjan (Ed.), Issledovanija po teorii grammatiki. Grammatičeskie kategorii v diskurse 4 (pp. 439-466). Moskva.

Daniël', M. A. (2009). Novyj' russkij vokativ: istorija formy usečennogo obraščenija skvoz' prizmu korpusa pis'mennyx tekstov. In K. L. Kiseleva, V. A. Plungjan, E. V. Raxilina, \& S. G. Tatevosov (Eds.), Korpusnye issledovanija po russkoj grammatike (pp. 224-244). Moskva.

Daniel, M., \& Spencer, A. (2009) The vocative - an outlier case. In A. Malchukov \& A. Spencer (Eds.), The Oxford handbook of case (Oxford handbooks in linguistics) (pp. 626-634). Oxford.

Diver, W. (1974). Substance and value in linguistic analysis. Semiotext(e)), 1(2), 13-30.

Diver, W. (1981). On defining the discipline. Columbia University working papers in linguistics, $6,59-117$.

Diver, W., \& Davis, J. (2012). Latin voice and case. In A. Huffman \& J. Davis (Eds.), Language: communication and human behavior. The linguistic essays of William Diver (pp. 195-245). Leiden.

Durst-Andersen, P. (1996). Russian case as mood. Journal of Slavic Linguistics, 4(2), 177-273.

Durst-Andersen, P. (2000). Predložno-padežnaja sistema russkogo jazyka. Ponjatie "kontakt nekontakt". In N. D. Arutjunova \& I. B. Levontina (Eds.), Jazyki prostranstv. Logičeskij analiz jazyka (pp. 135-151). Moskva.

Durst-Andersen, P. (2001). Possessum-oriented and possessor-oriented constructions in Russian. In I. Baron, M. Herslund, \& F. Sørensen (Eds.), Dimensions of possession (Typological studies in language 47) (pp. 99-113). Amsterdam, Philadelphia.

Durst-Andersen, P. (2002). Russian and English as two distinct subtypes of accusative languages. Scando-Slavica, 48, 103-126.

Durst-Andersen, P. (2011). Linguistic supertypes. A cognitive-semiotic theory of human communication (Semiotics, Communication and Cognition 6). Berlin, New York.

Durst-Andersen, P., \& Lorentzen, E. (2015a). Russian sentence adverbials: classification, orientation and representation. Russian linguistics, 39, 33-62.

Durst-Andersen, P., \& Lorentzen, E. (2015b). The syntax and semantics of Russian non-sentence adverbials. Scando-Slavica, 61(2), 221-260. 
Franks, S. (1995). Parameters of Slavic morphosyntax. New York \& Oxford.

Gagarina, N., Voeikova, M. (2009). Acquisition of case and number in Russian. In U. Stephany \& M. Voeikova (Eds.), Development of nominal inflection in first language acquisition: a cross-linguistic perspective (pp. 179-215). Berlin, New York.

Gvozdev, A. N. (1961 [1949]). Formirovanie u rebenka grammatičeskogo stroja russkogo jazyka. In A. N. Gvozdev. Voprosy izučenija detskoj reči. Čast’ 1, 2. (pp. 149-467). Moskva.

Harves, S. (2013). The genitive of negation in Russian. Language and Linguistics Compass, 7(12), 647-662. DOI: 10.1111/lnc3.12056.

Herslund, M. (1994). La notion d'incorporation en danois et en français”. Travaux de linguistique et de philologie, XXXII, 7-18.

Hjelmslev, L. (1972 [1935-1937]). La catégorie des cas. Étude de grammaire générale. München.

Jakobson, R. (1971 [1936]). Beitrag zur allgemeinen Kasuslehre. Gesamtbedeutungen der russischen Kasus. In R. Jakobson, Selected writings II. Word and language (pp. 23-71). The Hague.

Jakobson, R. (1971 [1958]). Morfologičeskie nabljudenija nad slavjanskim skloneniem. In R. Jakobson, Selected writings II. Word and language (pp. 152-186). The Hague.

Janda, L. A. (1993). A geography of case semantics. The Czech dative and the Russian instrumental. Berlin.

Janda, L. A., \& Clancy, S. J. (2002). The case book for Russian. Bloomington Indiana.

Karaulov, Ju. N. (1993). Associativnaja grammatika russkogo jazyka. Moskva.

Karcevski, S. (1927). Système du verbe russe. Essai de linguistique synchronique. Prague.

Kiebzak-Mandera, D. (2000). Formation of the verb system in Russian children. Psychology of Language and Communication, 4(1), 27-46. Retrieved from http://www.plc.psychologia.pl/plc/plc/contents/fulltext/04-1_2.pdf (12 May 2016).

Kilby, D. (1986). The instrumental in Russian: on establishing a consensus. In R. D. Brecht \& J. S. Levine (Eds.), Case in Slavic (pp. 323-337). Columbus, Ohio.

Klobukov, E. V. (1986). Semantika padežnyx form v sovremennom russkom literaturnom jazyke. (Vvedenie v metodiku pozicionnogo analiza). Moskva.

Knorina, L. V. (1996 [1981]). Ocenka semantičeskoj nagruzki padeža. In L. V. Knorina, Grammatika. Semantika. Stilistika. (Ed. V. A. Uspenskij). Moskva. Retrieved from: http://lidiaknorina.narod.ru/lingva.htm (7 May 2016). 
Kuryłowicz, J. (1949). Le probleme du classement des cas. Biuletyn Polskiego Towarzystwa Językoznawczego, 9, 20-43.

Kustova, G. I. (2011). Padež. In Materialy dlja proekta korpusnogo opisanija russkoj grammatiki. Na pravax rukopisi. Moskva. Retrieved from: http://rusgram.ru (22 April 2016).

Kustova, G. I. (2012). Datel'nyj padež. In Materialy dlja proekta korpusnogo opisanija russkoj grammatiki. Na pravax rukopisi. Moskva. Retrieved from: http://rusgram.ru (22 April 2016).

Kuznetsova, Ju., Plungian, V., Rakhilina, E. (2013). Time as secondary to space: Russian pod 'under' and iz-pod 'from-under' in temporal constructions. (Vremja kak periferija prostranstva: konstrukcii s predlogami pod i iz-pod $\mathrm{v}$ russkom jazyke). Russian linguistics, 37(3), 293-316. DOI 10.1007/s11185-013-9116-8.

Kuznecova, Ju., Rakhilina, E. (2015). Genitive of cause and cause of genitive. In P. Arkadiev, I. Kapitonov, Ju. Lander, E. Rakhilina, S. Tatevosov (Eds.), Donum semanticum: opera linguistica et logica in honorem Barbarae Partee a discipulis amicisque Rossicis oblate (pp. 135-148). Moscow. Retrieved from: https://publications.hse.ru/en/books/150350895 (14 May 2016).

Lakoff, G. (1987). Women, fire, and dangerous things: What categories reveal about the mind. Chicago.

Langacker, R. (1991). Foundations of cognitive grammar. Vol. II: Descriptive application. Stanford, California.

Levine, J. S. (1986). Remarks on the pragmatics of the "inalienable dative" in Russian. In R. D. Brecht \& J. S. Levine (Eds.), Case in Slavic (pp. 437-451). Columbus, Ohio.

Levine, J. S. (1990). Pragmatic implicatures and case: The Russian dative revisited. Russian Language Journal, 44 (147-149), 9-27.

Lopatin, V. V., \& Švedova, N. Ju. (Eds.) (1989). Kratkaja russkaja grammatika. Moskva.

Makarova, A., \& Nesset, T. (2013). Space-time asymmetries: Russian v 'in(to)' and the North Slavic temporal adverbial continuum (Prostranstevenno-vremennaja asimmetrija: russkij predlog $v$ i severno-slavjanskij kontinuum obstojayelstv vremeni). Russian Linguistics, 37(3), 317-345. DOI 10.1007/s11185-013-9115-9.

Malchukov, A., \& A. Spencer, (Eds.) (2009). The Oxford handbook of case (Oxford handbooks in linguistics). Oxford.

Manova, S. (2011). Understandning morphological rules: with special emphasis on conversion and subtraction in Bulgarian, Russian and Serbo-Croatian. New York, Heidelberg, London.

Mathiassen, T. (1996). Russisk grammatikk. Revidert utgave. Oslo.

Mel'čuk, I. A. (1986). Toward a definition of case. In R. Brecht \& J.S. Levine (Eds.), Case in Slavic (pp. 35-85). Columbus, $\mathrm{OH}$.

Mel'čuk, I. A. (1997). Kurs obščej morfologii. Tom II. Moskva, Vena. 
Mulisch, H. (1975). Die russische Sprache der Gegenwart. Band 2. Leipzig.

Mulisch, H. (1993). Handbuch der russischen Gegenwartssprache. Leipzig.

Nesset, T. (2004). Case assignment and image schemas: Russian temporal adverbials. Studies in Language, 28(2), 285-319.

Padučeva, E. V. (1960). Ob opisanii padežnoj sistemy russkogo suščestvitel'nogo (Nekotorye problemy omonimii pri mašinnom perevode). Voprosy jazykoznanija, 5, 104-111.

Padučeva, E. V. (2013). Russkoe otricatel'noe predloženie. Moskva.

Pajar, D., Plungjan, V. A. (2000). Predlog nad: fakty i interpretacii. In D. Pajar \& O. N. Seliverstova (Eds.), Issledovanija po semantike predlogov. Sbornik statej (pp. 83-114). Moskva.

Panov, M. V. (1980). O paradigmatike i sintagmatike. Izvestija AN SSSR. Serija literatury $i$ jazyka, 39(2), 128-137.

Panov, M. V. (1999). Pozicionnaja morfologija russkogo jazyka. Moskva.

Parrott, L. (2010). Vocatives and other direct address forms: a contrastive study. Oslo Studies in Language, 2(1), 211-229.

Partee, B., Borschev, V., Paducheva, E., Testelets, J., Yanovich, A. (2012). The role of verb semantics in genitive alternations: Genitive of negation and genitive of intensionality. OSLa - Oslo studies in language (The Russian verb), 4(1), 1-29. Retrieved from: https://www.journals.uio.no/index.php/osla/article/view/229 (14 May 2016).

Paus, Ch. (1994). Social and pragmatic conditioning in the demise of the Russian partitive case. Russian Linguistics, 18(3), 249-266.

Pesetsky, D. (2013). Russian Case Morphology and the Syntactic Categories. (Linguistic Inquiry Monographs Sixty-Six). Cambridge Massachusetts, London England.

Plungjan, V. A. (2002). K semantike russkogo lokativa ("vtorogo predložnogo" padeža). Semiotika i informatika, 37, 229-254.

Plungjan, V. A. (2011). Vvedenie v grammatičeskuju semantiku: grammatičeskie značenija $i$ grammatičeskie sistemy jazykov mira. Moskva.

Plungjan, V. A., Raxilina E. V. (2000). Po povodu "lokalistskoj” koncepcii značenija: predlog pod. In D. Pajar \& O. N. Seliverstova (Eds.), Issledovanija po semantike predlogov. Sbornik statej (pp. 115-133). Moskva.

Podlesskaya, V. I., Rakhilina, E. V. (1999). External possession, reflexivization and body parts in Russian. In D. L. Payne \& I. Barshi (Eds.), External possession (pp. 505-521). Amsterdam, Philadelphia PA.

Popova, Z. D. (1970). K teorii padežnogo značenija. Voprosy jazykoznanija, 4, 92-101.

Pul'kina, I. M., \& Zaxava-Nekrasova, E. B. (1975). Učebnik russkogo jazyka dlja studentovinostrancev: Praktičeskaja grammatika s upražnenijami. Izdanie 5-e, ispravlennoe. Moskva. 
Pupynin, Ju. A. (1996). Usvoenie sistemy russkix glagol'nyx form rebenkom (rannie ètapy). Voprosy jazykoznanija, 3, 84-94.

Rakhilina, E. (2004). On Genitive and 'Stability': Evidence from Russian. In Ji-Yung Kim, Y. A. Lander, \& B. H. Partee (Eds.), Possessives and beyond: semantics and syntax (UMOP 29) (pp. 45-58). Amherst, MA.

Rakhilina, E., Tribushinina, E. (2011). The Russian instrumental-of-comparison: constructional approach. In M. Grygiel, \& L. A. Janda, (Eds.), Slavic Linguistics in a Cognitive Framework (pp. 145-174). Frankfurt am Main, Berlin, Bern, Bruxelles, New York, Oxford, Wien.

Raxilina, E. (2008). Semantika russkix imennyx konstrukcij s genitivom: 'ustojčivost'. In J. Lindstedt et al. (Eds.), S ljubov'ju k slovu. Festschrift in Honour of Professor Arto Mustajoki on the Occasion of his 60th Birthday. Slavica Helsingiensia 35 (pp. 338-349). Helsinki.

Raxilina, E. V., Plungjan, V. A. (2014). Semantico-sintaksičeskie svojstva russkix konstrukcij s predlogom pod. Prjamye (prostranstvennye) i perenosnye (vremennýe) upotreblenija. Die Welt der Slaven. Internationale Halbjahresschrift für Slavistik, 59(1), 22-56.

Rosch, E. (1973). Natural categories. Cognitive Psychology, 4, 328-350.

Rozental', D. E. (Ed.) (1984). Sovremennyj russkij jazyk. Moskva.

Šarić, L. (2002). On the semantics of the "dative of possession" in the Slavic languages: An analysis on the basis of Russian, Polish, Croatian/Serbian and Slovenian examples. Glossos Journal, 3, 1-22.

Retrieved from: http://slaviccenters.duke.edu/uploads/media_items/3saric.original.pdf (15 May 2016).

Seliverstova, O. N. (1997). K voprosu o semantičeskoj strukture jazykovoj edinicy (na primere slov $u$ i rjadom). In L. P. Krysin (Ed.), Oblik slova. Sbornik statej (pp. 92-104). Moskva.

Seliverstova, O. N. (2000). Semantičeskaja struktura predloga na. In D. Pajar \& O. N. Seliverstova (Eds.), Issledovanija po semantike predlogov. Sbornik statej (pp. 189-242). Moskva.

Šeljakin, M. A. (2001). Funkcional'naja grammatika russkogo jazyka. Moskva.

Stepanov, Ju. S. (1968). Problema klassifikacii padežej (Sovmeščenie klassifikacij i ego sledstvija). Voprosy jazykoznanija, 6, 36-48.

Švedova, N. Ju., (Ed.) (1980). Russkaja grammatika. Tom 1, 2. Moskva.

Švedova, N. Ju., \& Lopatin, V. V. (1989). Kratkaja russkaja grammatika. Moskva.

Talmy, L. (1986). The relation of grammar to cognition. Berkeley Cognitive Science Report No. 45.

Timberlake, A. (1986). Hierarchies in the genitive of negation. In R. Brecht \& J.S. Levine (Eds.), Case in Slavic (pp. 338-360). Columbus, $\mathrm{OH}$. 
Timberlake, A. (2004). A reference grammar of Russian. Cambridge.

Tobin, Y. (1985). Case morphology and language teaching revisited. Papers in linguistics, 18(2), 259-294. DOI: 10.1080/08351818509389234.

Ufimceva, N. V. (1979). Psixolingvističeskie xarakteristiki funkcionirovanija kategorii padeža suščestvitel'nogo v russkom jazyke. In E. F. Tarasov, Ju. A. Sorokin, \& N. V. Ufimceva (Eds.), Psixolingvističeskie problemy grammatiki (pp. 5-65). Moskva.

Uspenskij, V. A. (1957). K opredeleniju padeža po A. N. Kolmogorovu. Bjulleten' Ob 'edinenija po problemam mašinnogo perevoda, 5, 11-18.

Voejkova, M. D. (2011). Imenitel'nyj padež. In Materialy dlja proekta korpusnogo opisanija russkoj grammatiki. Na pravax rukopisi. Moskva. Retrieved from: http://rusgram.ru (7 May 2016).

Wade, T. (1992). A comprehensive Russian grammar. Oxford.

Wade, T. (2011 [2010]). A comprehensive Russian grammar. Edited by D. Gillespie. Third edition, revised and expanded. UK.

Whorf, B. L. (1936). The Punctual and Segmentative Aspects of Verbs in Hopi. Language, 12(2), 127-131. DOI: 10.2307/408755.

Whorf, B. L. (1950). An American Indian model of the universe. International Journal of American Lingjistics, 16(2), 67-72.

Wierzbicka, A. (1980). The case for surface case. (Linguistica Extranea Studia 9). Ann Arbor.

Wierzbicka, A. (1983). The semantics of case marking. Studies in Language, 7, 247-75.

Wierzbicka, A. (1986). The meaning of case: a study of the Polish dative. In R. Brecht \& J.S. Levine (Eds.), Case in Slavic (pp. 386-426). Columbus, OH.

Wierzbicka, A. (1988). The semantics of grammar. Amsterdam.

Yadroff, M. (1996). Modern Russian vocatives: a case of subtractive morphology. Journal of Slavic Linguistics, 4(1), 133-153.

Zaliznjak, Andrej A. (1967). Russkoe imennoe slovoizmenenie. Moskva.

Zaliznjak, Andrej A. (1973). O ponimanii termina "padež" v lingvističeskix opisaniajx. In A. Zaliznjak (Ed.) Problemy grammatičeskogo modelirovanija (pp. 53-87). Moskva.

Zaliznjak, Anna A. (1996). The case for surface case reopened ili ešče raz o značenii russkogo tvoritel'nogo padeža. Die Welt der Slaven, XVI, 167-184.

Zel'dovič, G. M. (2012). Pragmatika grammatiki. Moskva.

Zubin, D. (1979). Discourse function of morphology: the focus system in German. In T. Givón (Ed.), Syntax and semantics vol. 12: discourse and syntax (pp. 469-504). New York. 
Žurinskaja, M. A. (1977). Imennye posessivnye konstrukcii i problema neottoržimoj prinadležnosti. In V. N. Jarceva (Ed.), Kategorija bytija i obladanija v jazyke (pp. 194-258). Moskva. 